\title{
Manuscript for Review
}

Autochthony, allochthony and the role of consumers in influencing the sensitivity of aquatic systems to nutrient enrichment.

Joseph D. Wood, David Elliott, Greg Garman, David Hopler, William Lee, Stephen McIninch, Aaron J. Porter, and Paul A. Bukaveckas Department of Biology and Center for Environmental Studies

Virginia Commonwealth University

Corresponding Author: Paul Bukaveckas (pabukaveckas@vcu.edu), Department of Biology and Center for Environmental Studies, Virginia Commonwealth University, 1000 West Cary Street, Richmond, VA, 23284

Submitted July 2015

Revised February 2016

Food Webs

Keywords: Eutrophication; grazing; subsidies; estuaries; Chesapeake Bay 


\section{Abstract}

Primary consumers may mitigate or exacerbate the effects of nutrient enrichment by grazing on plant matter and recycling nutrients. Few studies have quantified these effects for a suite of consumers and in the context of other processes regulating plant standing crop and nutrient supply. We quantified the abundance, feeding and diet of zooplankton, benthic filterfeeders, and planktivorous and detritivorous fish in the James River Estuary and found that consumer-mediated fluxes of CHLa and $\mathrm{N}$ were small in comparison to other fluxes regulating phytoplankton abundance (production, respiration, advection) and $\mathrm{N}$ availability (external inputs, internal recycling). Chlorophyll-a ingestion by consumers was equivalent to $15 \%$ of daily phytoplankton production and $\mathrm{N}$ recycling by consumers corresponded to $29 \%$ of phytoplankton $\mathrm{N}$ demand. The bulk of phytoplankton production (74\%) was lost to autotrophic and heterotrophic respiration. Recycling of $\mathrm{N}$ contained in autochthonous and allochthonous organic matter was sufficient to meet $100 \%$ of phytoplankton $\mathrm{N}$ demand with external inputs corresponding to $39 \%$ of phytoplankton $\mathrm{N}$ demand. Experiments using $2000 \mathrm{~L}$ outdoor mesocosms with natural plankton communities showed that the presence of consumers (shad) resulted in higher $\mathrm{N}$ availability, elevated CHLa and reduced macrozooplankton abundance. Overall, our study showed that the direct effect of consumers on fluxes of CHLa and N was small as the bulk of phytoplankton biomass and $\mathrm{N}$ passed to microbial decomposers. However selective grazing by planktivorous fishes reduced zooplankton densities resulting in greater phytoplankton yield at lower nutrient concentrations. 


\section{Introduction}

There is long-standing interest in the role of 'top-down' and 'bottom-up' forces in regulating material and energy cycling within ecosystems (Hairston et al. 1960; Oksanen et al. 1981). An applied aspect of this problem concerns top-down effects that may mitigate (via grazing) or exacerbate (via nutrient recycling) the effects of nutrient enrichment on aquatic primary production. These effects are of particular concern in phytoplankton-dominated waters where algal blooms cause deterioration of water quality (e.g., low dissolved oxygen, presence of algal toxins, etc.). The dual nature of consumer effects on phytoplankton complicates efforts to assess the sensitivity of waterbodies to nutrient enrichment and predict responses to nutrient reductions (Duarte et al. 2009; Carstensen et al. 2011). Reductions in nutrient loading have had variable success in mitigating symptoms of eutrophication; the lack of response is sometimes attributed to changes in top-down control arising from shifts in food web structure (Greening and Janicki 2006, Orth et al. 2010, Greening et al. 2011, Boynton et al. 2013, Verdonschot et al. 2013). Quantitative information on consumer control of phytoplankton abundance is important to the development of water quality models which are used to forecast recovery in response to reductions in nutrient loads. Model predictions are sensitive to assumptions regarding the magnitude and direction of consumer effects on phytoplankton abundance. For example, increased water residence time is predicted to favor high phytoplankton biomass due to lower advective losses. However in systems where benthic filter-feeders are abundant, expected relationships (e.g., between residence time and CHLa) may not be apparent as grazing effects intensify with longer residence time (Lucas and Thompson 2012; Peierls et al. 2012). Management strategies are predicated on understanding the relationship between nutrient inputs and phytoplankton biomass as these are used to establish maximum nutrient loads to protect aquatic life and other designated uses. Factors that alter this relationship limit our ability to identify appropriate nutrient reduction targets.

Primary consumers are important agents of top-down control as these are often numerically abundant (e.g., zooplankton, benthic filter-feeders; Borer et al. 2005; Caraco et al. 2006; Hall et al. 2007; Atkinson et al. 2014; Kimmerer and Thompson 2014) and exhibit large inter-annual variation (e.g., larval fishes; Cury et al. 2000). These consumers affect phytoplankton via multiple mechanisms including removal of biomass via grazing, regeneration of nutrients through excretion (consumer-mediated nutrient recycling) and alteration of 
community composition through selective grazing (Schaus et al. 2000; Friedland et al. 2005; Vanni et al. 2005; Jančula et al. 2008, Schmitz et al. 2008). In freshwaters, selective grazing that favors the dominance of cyanobacteria, particularly those associated with toxin production (e.g., Microcystin), is of special concern due to impacts on designated uses (drinking water, recreation, aquatic life). In addition to the complexities arising from multiple mechanisms of consumer control, there is also the issue of subsidies and how these might influence consumerphytoplankton relations. Allochthonous inputs subsidize secondary production and, by increasing consumer abundance, may strengthen top-down effects (Leroux and Loreau 2008). The importance of allochthonous inputs to aquatic food webs is well-documented (Vannote et al. 1980; Hoffman et al. 2007; Zeug and Winemiller 2008; Cole and Solomon 2012; Roach 2013; Dias et al. 2014), and yet there is little empirical data to assess the influence of allochthony on top-down control.

We examined the role of consumers in influencing phytoplankton abundance in the James River Estuary (tidal freshwater segment). Our goal was to determine whether consumers mitigate or exacerbate symptoms of nutrient enrichment such as algal blooms and presence of harmful cyanobacteria. This study was part of a broader effort to understand the factors contributing to the occurrence of algal blooms in this system, and to improve the reliability of models forecasting the effects of nutrient reduction on phytoplankton abundance and the occurrence of harmful cyanobacteria. We quantified grazing rates by zooplankton, benthic filterfeeders and fish, as well as their contributions to consumer-mediated nutrient recycling. Few studies have included all three groups of grazers and we are aware of no previously published study which quantifies the importance of grazing in the context of phytoplankton gains and losses through production, advection and decomposition. In addition, we considered the importance of consumer-mediated nutrient recycling in the context of other factors influencing $\mathrm{N}$ availability (biotic assimilation, external inputs and microbial recycling). Lastly, we combined our observational data with results from mesocosm experiments in which we manipulated consumer abundance. As our interest was in responses to anticipated nutrient load reductions, we tested the effects of consumer presence and absence along a nutrient reduction gradient.

\section{Methods}

\subsection{Study Site}


Our study site is the tidal freshwater segment (salinity $<0.5 \mathrm{ppt}$ ) of the James River, a sub-estuary of Chesapeake Bay, which is located in the mid-Atlantic region of the United States (Figure 1). This segment (Chesapeake Bay Program (CBP) designation JMSTF2) experiences high nutrient loads (446 $\mathrm{mg} \mathrm{TN} \mathrm{m}^{-2} \mathrm{~d}^{-1}$ and $55 \mathrm{mg} \mathrm{TP}^{-2} \mathrm{~d}^{-1}$ ) due to a large watershed relative to surface area, and local point source inputs from the Richmond, VA metropolitan region (Bukaveckas and Isenberg 2013). Nutrient inputs, and favorable water residence time result in high phytoplankton standing stock (CHLa typically 30-60 $\mu \mathrm{g} \mathrm{L-1)}$ and high phytoplankton production during May to September (Bukaveckas et al. 2011; Wood and Bukaveckas 2014). Bioassay results show that phytoplankton are N-limited, and occasionally co-limited by $\mathrm{N}$ and $\mathrm{P}$, but do not respond to additions of $\mathrm{P}$ alone (Wood and Bukaveckas 2014). Contributions from benthic algae and aquatic macrophytes to ecosystem primary production are small due to shallow photic depths $(40-60 \mathrm{~cm})$ relative to total depth $($ mean $=3.1 \mathrm{~m})$. Phytoplankton communities are dominated by diatoms and chlorophytes, but a small contribution from cyanobacteria (typically $5-10 \%$ of biomass) has resulted in widespread occurrence of Microcystin in water and tissues of fish and shellfish (Wood et al. 2014). The segment is considered 'impaired' for exceeding numeric chlorophyll-a (CHLa) standards and is subject to nutrient reduction targets which are expected to improve local water quality and reduce nutrient loads to Chesapeake Bay. Three of our weekly monitoring stations are located within this segment (CBP designations JMS75, JMS69 and JMS55; values denote distance in miles from river mouth) and a continuous monitoring station is located at the VCU Rice Center research pier (near JMS75; Figure 1). This segment of the James is vertically and laterally well-mixed owing to fluvial inputs (freshwater replacement time $=5-25$ days $)$ and a large tidal prism $(60 \mathrm{~cm})$ relative to depth $($ Wood and Bukaveckas 2014).

\subsection{Grazing and Consumer-mediated Nutrient Cycling}

Quantifying rates of grazing and nutrient cycling requires estimates of consumer abundance and per capita consumption. We used a combination of site-specific and literaturebased data to characterize grazing rates and nutrient recycling by zooplankton, benthic filterfedders, and planktivorous and detritivorous fishes. Zooplankton communities in the tidal fresh segment are dominated by rotifers, Bosmina (Cladocera: Bosminidae) and Eurytemora (Calanoida: Temoridae) (Bukaveckas et al. 2011). Wedge clams (Rangia cuneate; Eulamellibranchia: Mactridae) are the dominant benthic filter-feeders in the tidal freshwater zone 
of the James and other sub-estuaries of Chesapeake Bay (Gerritsen et al. 1994; Cerco \& Noel 2010). Abundant fish species include the planktivorous Threadfin Shad (Clupeiformes: Clupeidae), Gizzard Shad (Clupeiformes: Clupeidae) and Atlantic Menhaden (Clupeiformes: Clupeidae), as well as Blue Catfish (Siluriformes: Ictaluridae ), which are benthivorous as juveniles (Schloesser et al. 2011). Data collected for this study included estimates of zooplankton and fish abundance, fish diet analysis (gut contents and stable isotopes), and measurement of grazing rates by benthic filter-feeders (Table 1). All data were collected between March and November in 2012 and 2013. Due to the variable sampling times for the various consumers, we do not attempt to characterize their seasonal patterns, but instead present average grazing rates for this period for comparison to other fluxes. Specifically, we compared phytoplankton production to losses via grazing, decomposition and downstream export. Similarly, we compared nutrient recycling by consumers to algal nutrient demand, external inputs from the watershed and nutrient regeneration via microbial decomposition. For nutrient recycling, we focused on $\mathrm{N}$ as phytoplankton in the tidal fresh segment are N- or co- (N-P) limited (Wood and Bukaveckas 2014).

\subsubsection{Fish Abundance and Dietary Analyses}

Fish abundance was estimated using low and high frequency electrofishing. Five to ten randomly located $500 \mathrm{~m}$ transects were sampled in each of three areas: City Point, Rice Center, and Tar Bay (Figure 1). The transects encompassed both main channel and shallow water habitats with separate transects for high vs. low frequency electrofishing. Low frequency electrofishing was used to estimate Blue Catfish abundance; high frequency electrofishing was used for all other species. The boat sampled a volume $500 \mathrm{~m}$ in length, $5 \mathrm{~m}$ in width, and equal to the depth of the system. During high frequency electrofishing, all fish within the reference area were collected for identification. For low frequency electrofishing, catfish appearing within the 5-m span were counted and assigned to one of three size categories $(<20 \mathrm{~cm}, 20-40 \mathrm{~cm}$, and $>40 \mathrm{~cm}$ ). For each transect, 10 randomly selected fish of each species were measured for length and weight. Sampling was conducted in September 2012, June 2013 and August 2013. Fish abundances were expressed relative to the sampling volume (the product of transect area and mean depth).

CHLa and PON consumption by Gizzard Shad (YOY and adult), Threadfin Shad, Atlantic Menhaden and juvenile Blue Catfish $(<20$ and 20-40 cm) were derived from estimates 
of abundance, samples of gut contents and an assumed gastric evacuation rate. As our interest was in grazing and nutrient recycling, we did not perform a detailed gut contents analysis, but rather, measured the CHLa, $\mathrm{C}$ and $\mathrm{N}$ content of gut material to estimate CHLa ingestion and $\mathrm{N}$ excretion. Approximately 500 fish were collected for gut contents analyses from monthly sampling during April to October 2012. The number and types of fish obtained were sufficient to derive 34 monthly, taxa-specific estimates of a possible 42 taxa-month combinations for the 6 taxa-size groupings. Gut contents were removed surgically for determination of wet weight and dry weight $\left(60^{\circ} \mathrm{C}\right.$ for $\left.48-72 \mathrm{~h}\right)$. Sub-samples of gut contents were taken to determine CHLa, C and $\mathrm{N}$ content for each sample. $\mathrm{C}$ and $\mathrm{N}$ content was determined using a Perkin-Elmer CHN Analyzer; CHLa samples were extracted overnight in 90\% buffered acetone prior to analysis on a TD-700 fluorometer. Prior work has shown that degradation of CHLa can occur during passage from the foregut to the hindgut (Friedland et al. 2005). Therefore, in addition to estimating CHLa ingestion directly from CHLa in gut contents, we also estimated CHLa consumption based on the amount of organic matter found in gut contents and the measured CHLa content of suspended particulate matter. The CHLa:C ratio of suspended particulate matter was derived from the slope of a regression relating paired measurements of CHLa and POC using bi-monthly data from three stations (JMS75, JMS69 and JMS56) obtained during March-October 2012-13 $\left(\mathrm{n}=108, \mathrm{R}^{2}=0.70, \mathrm{p}<0.0001\right)$. The CHLa content of suspended particulate matter $(\mathrm{CHLa}: \mathrm{C}=$ $12.2 \pm 0.8 \mu \mathrm{g}: \mathrm{mg}$ ) was appreciably higher than that of gut contents from planktivorous fishes $(0.17-0.23 \mu \mathrm{g}: \mathrm{mg})$ thereby resulting in higher estimates of the amount of CHLa consumed than those derived from measured CHLa in gut contents. For benthivorous fishes we substituted the $\mathrm{C}$ :CHLa ratio of surficial sediments $(0.27 \mu \mathrm{g}: \mathrm{mg})$ to estimate CHLa ingestion. We used these higher estimates of CHLa consumption to account for post-consumption degradation of CHLa. In addition to fish abundance and gut contents data, estimation of ingestion rates requires knowledge of gut clearance or turnover times, which are known to vary among species and food conditions. We considered a range of gastric turnover times (4-18 $\mathrm{d}^{-1}$; Shepherd and Mills 1996) to derive a potential range of CHLa consumption and $\mathrm{N}$ recycling rates.

\subsubsection{Grazing by Zooplankton and Rangia}

Methods for determining Rangia clearance rates were described in Wood et al. (2014) and are briefly summarized here. Monthly experiments were performed during March-October 2012 using James River water and clams collected near the VCU Rice Center. Clams were 
obtained using oyster tongs and kept overnight for acclimation to experimental conditions. The experimental design followed Wong et al. (2010) whereby we monitored CHLa and PON concentrations (at 0,2 and $4 \mathrm{~h}$ ) in $20 \mathrm{~L}$ mesocosms with and without clams (3 replicates of each). Mesocosm were kept in low light to minimize phytoplankton growth during the experiment and equipped with a circulating pump to maintain particulates in suspension. Differences in the slopes of regression lines (concentration vs. time) between mesocosms with and without clams were used to estimate clearance rates. This rate is a theoretical value representing the volume of water cleared of CHLa or PON based on the mass removed by consumers and average concentration in the water (Coughlan 1969). Each mesocosm contained a similar mass of clams (3-10 individuals depending on size; average body mass ( $\mathrm{soft}$ tissue $)=2.6 \mathrm{~g} \mathrm{ind}^{-1}$; range $=0.5$ to $5.0 \mathrm{~g} \mathrm{ind}^{-1}$ ). Clearance rates were expressed per unit of body mass. Samples for CHLa analysis were filtered thru Whatman GF/A glass filters $(0.5 \mu \mathrm{m}$ nominal pore size $)$ and extracted overnight in $90 \%$ buffered acetone prior to analysis on a TD-700 fluorometer. PON was determined on a Perkin-Elmer CHN analyzer. The abundance of wedge clams in the James is determined annually through benthic surveys conducted by CBP (Cerco and Noel 2010; Sturdivant et al. 2014). We used the long-term (2001-2010) annual average abundance and the average of the monthly measured clearance rates to derive the average rate of CHLa and PON ingestion by Rangia.

Zooplankton grazing and nutrient recycling was estimated based on measured abundance and previously-published species-specific per capita clearance rates. Zooplankton abundance in the James was measured bi-monthly during March-September 2013 (total = 13 collections). Triplicate vertical net tows were collected at a single station (JMS75) and retained for identification and enumeration (within 1 week of collection). For nauplii, copepods and cladocerans, samples were obtained with a $64 \mu \mathrm{m}$ mesh, $0.5 \mathrm{~m}$ diameter net. Dead animals, as indicated by aniline blue staining, were not included in final abundance estimates used to calculate grazing (Elliott and Tang 2011). For rotifers, a $20 \mathrm{~L}$ depth-integrated sample was passed through a $20 \mu \mathrm{m}$ mesh net and preserved in Lugol's until analysis (Chick et al. 2010). Clearance rates were obtained from the literature for the dominant species occurring in the James: rotifers $=0.38 \mathrm{ml}_{\text {ind }}^{-1} \mathrm{~d}^{-1}$ (Sierzen \& Frost 1990), Bosmina $=1.63 \mathrm{ml} \mathrm{ind}^{-1} \mathrm{~d}^{-1}($ Sierzen \& Frost 1990), Eurytemora adults and copepodids $=9.67 \mathrm{ml} \mathrm{ind}^{-1} \mathrm{~d}^{-1}$ (Sierzen \& Frost 1990), and copepod nauplii $=2.00 \mathrm{ml} \mathrm{ind}^{-1} \mathrm{~d}^{-1}$ (Bogdan \& Gilbert 1984). Clearance rates were used in 
conjunction with measured concentrations of CHLa and PON (at JMS75) to determine CHLa removal and $\mathrm{N}$ cycling by zooplankton.

\subsubsection{Grazing in the Context of Other Fluxes}

CHLa production $\left(\mu \mathrm{g} \mathrm{L}^{-1} \mathrm{~d}^{-1}\right)$ was derived from measurements of daily NPP and an empirically-determined CHLa:C ratio for the James (see above). Phytoplankton DIN demand was similarly derived from NPP and the Redfield C:N ratio. Daily primary production was calculated from diel oxygen data measured at the VCU Rice Rivers Center (near JMS75) during March-November of 2012 and 2013. Use of a single-station diel method to derive metabolism estimates is potentially complicated by tidal influences on local $\mathrm{O}_{2}$ concentrations. After detrending the diel data for a 24-h cycle we did not find that tidal intervals explained a significant fraction of the residual variation and therefore concluded that a single-station method was appropriate for this site. Methods of computation were previously described by Bukaveckas et al. (2011) and follow those used by Caffrey $(2003,2004)$ for National Estuarine Research Reserve sites. Dissolved $\mathrm{O}_{2}$ concentrations recorded at 15-min intervals were smoothed to 30min averages for flux analyses. We derived daily NPP from the sum of daytime $\mathrm{O}_{2}$ fluxes and daily $\mathrm{R}$ from the sum of nighttime $\mathrm{O}_{2}$ fluxes extrapolated to $24 \mathrm{~h}$. Derivation of NPP and $\mathrm{R}$ from diel data requires correction for atmospheric exchange. Air-water $\mathrm{O}_{2}$ fluxes were calculated assuming that atmospheric exchange varied only in response to dissolved $\mathrm{O}_{2}$ saturation. This approach uses a fixed gas-transfer coefficient which yields a range of exchange rates from -0.5 to $+0.5 \mathrm{~g} \mathrm{O}_{2} \mathrm{~m}^{-2} \mathrm{~h}^{-1}$ for $0-200 \%$ saturation. We had previously compared these fixed estimates to those corrected for variable wind speed (Marino \& Howarth 1993) and found that the latter yielded a similar range of exchange values $\left(-0.3\right.$ to $\left.+0.3 \mathrm{~g} \mathrm{O}_{2} \mathrm{~m}^{-2} \mathrm{~h}^{-1}\right)$ for wind speeds observed at this site. $\mathrm{O}_{2}$-based NPP and $\mathrm{R}$ values were converted to $\mathrm{C}$ assuming a photosynthetic and respiratory quotient of 1.0 .

Determination of respiratory losses of CHLa requires partitioning total respiration into fractions supported by autochthonous production and allochthonous inputs. We used the method of del Giorgio and Peters (1994) whereby the y-intercept for the regression of R vs. NPP is taken to represent the fraction of $\mathrm{R}$ that is supported by allochthonous inputs (i.e., $\mathrm{R}$ at NPP=0). Our regression was based on pooled 2012 and 2013 data and yielded an estimate for allochthonous-R of $2.0 \pm 0.2 \mathrm{mg} \mathrm{O}_{2} \mathrm{~m}^{-2} \mathrm{~d}^{-1}\left(\mathrm{R}^{2}=0.51, \mathrm{p}<0.0001\right)$. When subtracted from total- $\mathrm{R}$ (mean $=5.6$ $\mathrm{mg} \mathrm{O}_{2} \mathrm{~L}^{-1} \mathrm{~d}^{-1}$ ) this provided an estimate of autochthonous- $\mathrm{R}$ of $3.6 \mathrm{mg} \mathrm{O}_{2} \mathrm{~L}^{-1} \mathrm{~d}^{-1}$. This value was 
used along with the previously-referenced C:CHLa ratio to estimate daily loss of CHLa due to respiration. Internal re-generation of DIN via microbial decomposition was derived similarly except that we used the $C: N$ content of autochthonous (Redfield $=6.6)$ and allochthonous $(C: N=$ 15.1) organic matter in combination with autochthons-R and allochthonous- $R$. The allochthonous $\mathrm{C}: \mathrm{N}$ ratio was determined from seston samples collected at the Fall Line (CBP stations JMS110) during periods of high discharge in Spring 2011. We estimate that autochthonous contributions to these samples were less than $10 \%$ (see Stable Isotopes, below). CHLa and $\mathrm{N}$ associated with respiring organic (autochthonous or allochthonous) matter was assumed to be respectively degraded or regenerated.

Lastly, we estimated export losses of CHLa via advection downstream and DIN inputs from external sources for comparison to consumer-mediated fluxes. DIN loads to the tidal fresh segment include riverine inputs at the Fall Line as well as local point source discharges; these were previously estimated to be $0.125 \mathrm{mg} \mathrm{DIN} \mathrm{L}^{-1} \mathrm{~d}^{-1}$ (Bukaveckas \& Isenberg 2013). Net loss of CHLa from the study reach was derived as the difference between input fluxes (riverine CHLa) and downstream export (advective loss). Input fluxes were derived as the product of riverine discharge (USGS gauges on the James and Appomattox Rivers; \#2037500 and \#2041650, respectively) and weekly CHLa concentrations at a station (JMS99) located above our study reach. Export losses were derived as the product of riverine discharge and the average CHLa concentration at three stations located within our study reach (JMS75, JMS69 and JMS56), which were sampled weekly during March-November of 2012 and 2013 (Wood and Bukaveckas 2014). To obtain daily flux estimates, we interpolated CHLa concentrations based on regressions with discharge. Daily input and output fluxes were summed and converted to average daily volumetric values $\left(\mu \mathrm{g} \mathrm{L}^{-1} \mathrm{~d}^{-1}\right)$ that represent the net gain or loss of CHLa from the study reach. We did not consider the effects of tidal exchange on the CHLa balance of the study reach as our prior analysis showed that the net difference between incoming and outgoing tidal fluxes was small (Bukaveckas and Isenberg 2013). Approximately 98\% of the outgoing tide was returned on the subsequent incoming tide based on a $\mathrm{Cl}$ mass balance analysis.

\subsection{Stable Isotope Analysis}

We determined the $\mathrm{C}$ and $\mathrm{N}$ stable isotopic composition of autochthonous and allochthonous inputs to the estuary, and of the primary consumers. These results were used to corroborate data on CHLa ingestion based on gut contents analysis of fish, and to assess the 
potential importance of autochthonous food sources to consumers for which we lacked dietary data (zooplankton and Rangia). We followed preparation protocols of, and submitted samples to, the UC-Davis Stable Isotope Lab. Seston samples were analyzed using an Elementar Vario EL Cube or Micro Cube elemental analyzer interfaced to a PDZ Europa 20-20 isotope ratio mass spectrometer. Tissue samples were analyzed using a PDZ Europa ANCA-GSL elemental analyzer interfaced to a PDZ Europa 20-20 isotope ratio mass spectrometer. We analyzed 10-15 individuals for each taxa among the primary consumers with the exception of zooplankton for which we analyzed 6 mixed-taxa samples containing the dominant macrozooplankton. Fish were collected monthly during 2012 in conjunction with the gut contents analysis. Rangia were collected monthly during 2013 in conjunction with grazing rate measurements. Zooplankton were collected monthly at a single station (JMS75) in conjunction with estimation of their abundance. We determined the stable isotopic composition of allochthonous inputs by analyzing seston samples obtained at the Fall Line during high discharge conditions in March and April 2011. We assumed that during these conditions the samples would be dominated by terrestrial sources of organic matter with minimal contribution from autochthonous sources (e.g., riverine phytoplankton). Particulate matter in these samples was characterized by high TSS (100-300 mg $\left.\mathrm{L}^{-1}\right)$ and $\mathrm{C}: \mathrm{N}$ (11-15 as molar) with low organic matter content $(<10 \%)$. The stable isotopic composition of autochthonous organic matter was represented by monthly samples collected within the estuary (stations JMS75, JMS69 and JMS56) during summer low-discharge conditions (May-October). These samples were characterized by low TSS (10-20 $\mathrm{mg} \mathrm{L}^{-1}$ ) and C:N (6-7) with high organic matter (25-50\%) and CHLa (20-50 $\left.\mu \mathrm{g} \mathrm{L}^{-1}\right)$ content. For comparison, we also determined the stable isotopic composition of surficial $(0-2 \mathrm{~cm})$ sediments obtained monthly from the same segment of the estuary as for seston and consumer samples.

\subsection{Mesocosm Experiment}

A mesocosm experiment was performed in July 2013 to assess the effects of nutrient reductions on phytoplankton in the presence and absence of consumers (Rangia, shad). The mesocosms (2000 L fiberglass tanks) were filled directly from the James River (intake at Rice Research Pier) to obtain a natural complement of phyto- and zoo- plankton communities. The tanks are located outdoors and experience natural photoperiod and diel temperature variations.

The tanks were partially covered so that depth-averaged underwater irradiance $\left(4.8 \mathrm{E} \mathrm{m}^{-2} \mathrm{~d}^{-1}\right.$ at typical daily PAR) approximated the depth-averaged irradiance of a $2.5 \mathrm{~m}$ water column taking 
into account light attenuation in the tidal fresh James (mean $\mathrm{k}_{\mathrm{d}}=3.14 \pm 0.33 \mathrm{~m}^{-1}$; Bukaveckas et al. 2011; Wood and Bukaveckas 2014). A total of 16 tanks were used with 4 tanks randomly assigned to each of 4 treatment groups: Control, Sediment, Clams and Shad. The Sediment treatment was included to contrast two mechanisms of internal nutrient regeneration (consumermediated and sediment release) that could mitigate phytoplankton responses to nutrient reductions. Ten buckets (4 L) containing sediment collected from near-shore areas of the James (Ekman sampler) were placed in each Sediment tank so that the water volume to sediment surface area ratio corresponded to a $2.5 \mathrm{~m}$ water column. Rangia collected from the James were placed in $16 \mathrm{~L}$ plastic baskets and suspended in each Clam tank at densities approximating those of the James (5 ind per tank). Planktivorous fish (YOY Gizzard Shad and Threadfin Shad) were collected by electrofishing and acclimated in holding tanks for 2-3 days prior to the start of each experiment. Three fish were transferred into each Shad tank to approximate densities in the James ( 3 ind per tank). Each of the four treatments was replicated among 4 tanks comprising an oligotrophication gradient. The highest level of nutrient addition $\left(0.12 \mathrm{mg} \mathrm{DIN} \mathrm{L}^{-1} \mathrm{~d}^{-1}, 0.03 \mathrm{mg}\right.$ $\mathrm{PO}_{4} \mathrm{~L}^{-1} \mathrm{~d}^{-1}$ ) corresponded to the current nutrient loading rate for the tidal fresh James (Bukaveckas and Isenberg 2012, Wood and Bukaveckas 2014). Other tanks received zero, 33\% (0.04 mg DIN L $\left.\mathrm{m}^{-1}, 0.01 \mathrm{mg} \mathrm{PO}_{4} \mathrm{~L}^{-1} \mathrm{~d}^{-1}\right)$ and 66\% (0.08 mg DIN L $\mathrm{m}^{-1} \mathrm{~d}^{-1}, 0.02 \mathrm{mg} \mathrm{PO}_{4} \mathrm{~L}^{-1} \mathrm{~d}^{-1}$ ) of this loading rate. DIN additions consisted of $65 \% \mathrm{NH}_{4}$ (as $\left.\mathrm{NH}_{4} \mathrm{Cl}\right)$ and $35 \% \mathrm{NO}_{3}\left(\mathrm{NaNO}_{3}\right)$ which is representative of their relative contribution to DIN loading to the James (Bukaveckas and Isenberg 2012). Nutrients were added every three days during the 15-day experiment. The length of the experiment corresponded to typical freshwater replacement times in the James (e.g., mean=16 d for May-October 2012; Wood and Bukaveckas 2014).

CHLa was measured every $3 \mathrm{~d}$ throughout the experiment; nutrients $\left(\mathrm{TN}, \mathrm{TP}, \mathrm{NH}_{4}, \mathrm{NO}_{3}\right.$, and $\mathrm{PO}_{4}$ ), zooplankton, Microcystin and genetic markers specific to Microcystis (16S rDNA copies) were sampled on days 0,6 and 15. Methods for nutrient, Microcystin and genetics analysis were described in Wood et al. (2014). Zooplankton were collected by filtering $2 \mathrm{~L}$ of water through a $20 \mu \mathrm{m}$ mesh sieve. Mesocosm data were analyzed by ANCOVA using JMP Pro 10 to test for significant nutrient, grazer and interaction effects.

\section{Results}

\subsection{CHLa Consumption and N Cycling by Consumers}


Fish abundance and diet data show that planktivores, particularly Threadfin Shad, were the dominant consumers of CHLa among fishes in the tidal fresh James (Figure 2). Threadfin Shad had a high CHLa content in their diet $\left(175 \pm 21 \mu \mathrm{g} \mathrm{CHLa} \mathrm{g} \mathrm{DW}^{-1}\right)$ as did other pelagicfeeding species (YOY Gizzard Shad $=198 \pm 24 \mu \mathrm{g}$ CHLa g DW ${ }^{-1}$; Atlantic Menhaden $=77 \pm 12$ $\mu \mathrm{g}$ CHLa g DW ${ }^{-1}$ ). By comparison, benthivorous fishes had low CHLa in their diet (adult Gizzard Shad $=44 \pm 6 \mu \mathrm{g}$ CHLa $\mathrm{g} \mathrm{DW}^{-1}$; two size classes of juvenile Blue Catfish: 34 and $45 \mu \mathrm{g}$ CHLa D $^{-1}$ ). Threadfin Shad were also the most abundant taxa accounting for almost half of total fish density. Threadfin Shad accounted for $65 \%$ of fish CHLa consumption despite their small individual size $\left(6.5 \mathrm{~g}\right.$ ind $\left.^{-1}\right)$. YOY Gizzard Shad were the second most important contributor accounting for $25 \%$ of fish CHLa consumption. The combined CHLa consumption of benthivorous fishes was less than $3 \%$ of the total, despite accounting for $90 \%$ of fish biomass, due to the low amount of CHLa in their diets. Total CHLa ingestion by planktivorous and benthivorous fish was low $\left(0.36 \mu \mathrm{g} \mathrm{CHLa} \mathrm{L}{ }^{-1} \mathrm{~d}^{-1}\right)$ even when using maximal gut clearance rates and correcting for post-consumption CHLa degradation.

Though not important as consumers of CHLa, benthivorous fishes, particularly adult Gizzard Shad, accounted for a large proportion of fish PON ingestion (Figure 3). PON of diet materials was similar among all fishes (mean $=36.2 \mathrm{mg} \mathrm{N} \mathrm{g} \mathrm{DW}^{-1}$; range $=31.1$ to $49.1 \mathrm{mg} \mathrm{Ng}$ $\mathrm{DW}^{-1}$ ) and therefore relative contributions to $\mathrm{N}$ recycling were largely determined by per capita ingestion rates (a function of body size) and numerical abundance. The large body size of adult Gizzard Shad $\left(\right.$ mean $=386 \mathrm{~g}$ ind ${ }^{1}{ }^{1}$ ) yielded a proportionally large mass of gut contents and the highest per capita PON ingestion rate. For the range of gut turnover times considered (4-18 d${ }^{1}$ ), we estimate that adult Gizzard Shad consume 330 to $1,480 \mu \mathrm{g}$ PON ind ${ }^{-1} \mathrm{~d}^{-1}$. Adult Gizzard Shad were also the most abundant group by biomass $\left(3.9 \mathrm{~g} \mathrm{~m}^{-3}\right)$ accounting for $60 \%$ of total fish biomass. This resulted in a population-scale estimate of PON consumption that was highest among the 6 taxa-size groups.

Rotifers and wedge clams (Rangia) were the dominant consumers of CHLa and PON among invertebrates (Figure 4). Rotifers (principally Brachionus calyciflorus) were important consumers despite their low per capita grazing rates $\left(0.38 \mathrm{ml} \mathrm{ind}^{-1} \mathrm{~d}^{-1}\right)$ due to their high densities $\left(\right.$ mean $=154,000 \pm 13,500 \mathrm{ind} \mathrm{m}^{-3}$ ) which yielded consumption estimates of $1.1 \mu \mathrm{g} \mathrm{CHLa} \mathrm{L}^{-1} \mathrm{~d}^{-1}$ and $20 \mu \mathrm{g} \mathrm{PON} \mathrm{L}^{-1} \mathrm{~d}^{-1}$. Rangia abundance was orders of magnitude lower (mean $=10 \pm 2 \mathrm{ind} \mathrm{m}^{-}$ $\left.{ }^{3}\right)$ but their clearance rates were correspondingly higher $\left(7,400 \mathrm{ml}\right.$ ind $\left.{ }^{-1} \mathrm{~d}^{-1}\right)$ which resulted in 
similar consumption rates $\left(1.4 \mu \mathrm{g}\right.$ CHLa L ${ }^{-1} \mathrm{~d}^{-1}$ and $21 \mu \mathrm{g}$ PON L $\left.^{-1} \mathrm{~d}^{-1}\right)$ to rotifers. Other zooplankton (Bosmina, Eurytemora, copepod nauplii) did not contribute appreciably to CHLa or PON consumption. Combined rates of CHLa consumption for invertebrates $\left(2.7 \mu \mathrm{g} \mathrm{L}^{-1} \mathrm{~d}^{-1}\right)$ were almost an order of magnitude higher than those for fish $\left(0.36 \mu \mathrm{g} \mathrm{L}^{-1} \mathrm{~d}^{-1}\right)$. The combined PON consumption by invertebrates $\left(45 \mu \mathrm{g} \mathrm{L}^{-1} \mathrm{~d}^{-1}\right)$ was two-fold higher than fish $\left(27 \mu \mathrm{g} \mathrm{L}^{-1} \mathrm{~d}^{-1}\right)$.

Phytoplankton production expressed as CHLa averaged $20.1 \mu \mathrm{g} \mathrm{L}^{-1} \mathrm{~d}^{-1}$ during MarchNovember of 2012 and 2013 (Figure 5). Respiratory losses accounted for $14.8 \mu \mathrm{g} \mathrm{L}^{-1} \mathrm{~d}^{-1}$ (74\%) of production. By comparison, losses due to the combined grazing of fish, zooplankton and Rangia were $3.1 \mu \mathrm{g} \mathrm{L}^{-1} \mathrm{~d}^{-1}$ (15\% of production). Export losses were also small $\left(0.9 \mu \mathrm{g} \mathrm{L}^{-1} \mathrm{~d}^{-1}\right)$ corresponding to $4 \%$ of production. The sum of all three losses accounted for $93 \%$ of the estimated CHLa production. The combined PON ingestion rate for all grazers was $72 \mu \mathrm{g} \mathrm{L}^{-1} \mathrm{~d}^{-1}$ suggesting that consumer-mediated recycling could contribute $25 \%$ of daily phytoplankton $\mathrm{N}$ demand $\left(290 \mu \mathrm{g} \mathrm{L}^{-1} \mathrm{~d}^{-1}\right)$. By comparison, our estimate of $\mathrm{N}$ re-mineralization based on respiration of allochthonous and autochthonous organic matter $\left(291 \mu \mathrm{g} \mathrm{L}^{-1} \mathrm{~d}^{-1}\right)$ could potentially account for $100 \%$ of daily phytoplankton $\mathrm{N}$ demand. External inputs of DIN $\left(108 \mu \mathrm{g} \mathrm{L}^{-1} \mathrm{~d}^{-1}\right)$ were equivalent to $39 \%$ of daily phytoplankton demand.

\subsection{Stable Isotopes}

Inter-specific differences in the stable isotopic ratios of fish followed differences in the CHLa content of their dietary materials (Figure 6). Planktivorous fishes with high CHLa in their gut contents (Threadfin Shad, YOY Gizzard Shad and Atlantic Menhaden) exhibited depleted $\delta^{13} \mathrm{C}$ (means $=-28.2,-27.3$ and $-27.8 \%$, respectively; Table 2) relative to benthivorous fishes (juvenile Blue Catfish $=-25.7 \%$, adult Gizzard Shad $=-25.1$ ) with low CHLa in gut contents. Estuarine seston collected during peak CHLa was depleted in $\delta^{13} \mathrm{C}($ mean $=-29.0 \%$ ) relative to riverine seston collected during high discharge (mean $=-26.8 \%$ ). The $\delta^{13} \mathrm{C}$ of sediment (mean $=-26.7 \%$ ) was similar to that of riverine seston. We recognize that our estuarine seston samples over-estimate $\delta^{13} \mathrm{C}$ of autochthonous sources due to contributions from $\delta^{13} \mathrm{C}$-enriched sediments, which are maintained in suspension by tidal forces. Based on the CHLa content of the seston samples and a site-specific C:CHLa ratio, we estimated that algae comprised on average $60 \%$ of the organic matter of estuarine seston, whereas the riverine samples were less than $10 \%$ algal $\mathrm{C}$. A simple mixing model based on these estimated algal contributions allowed us to derive theoretical end members for autochthonous $(-30.4 \%)$ and allochthonous $(-26.5 \%)$ organic 
matter. We extrapolated these values to higher trophic levels using trophic fractionation factors $(\mathrm{C}=0.4 \pm 0.2 \% ; \mathrm{N}=3.4 \pm 1.2 \%$; McCutchan et al. 2003) to provide a qualitative basis for assessing the importance of autochthonous and allochthonous sources for primary consumers (Figure 6$). \quad \delta^{13} \mathrm{C}$ of zooplankton (mean $=-29.3 \%$ ) and planktivorous fishes fell within the expected range for consumers supported by autochthonous sources. $\delta^{13} \mathrm{C}$ of Rangia (mean $=$ 25.8) and benthivorous fish were similar to predicted values for consumers dependent on allochthonous organic matter. As overall biomass in this food web was dominated by benthivorous fish and Rangia, these results suggest that metazoan production in this estuary was largely supported by allochthonous inputs.

\subsection{Mesocosm Experiments}

In controlled experiments, the presence of consumers was found to ameliorate the effects of nutrient reductions on phytoplankton abundance. DIN and $\mathrm{PO}_{4}$ concentrations decreased proportionately along the nutrient gradient, but DIN concentrations were significantly higher among tanks with consumers (Shad, Rangia) relative to those without (Control, Sediment; $\mathrm{p}=$ 0.003 ) at all levels of nutrient addition. CHLa concentrations declined in response to nutrient reductions in all treatments, with smallest reductions observed in mesocosms with Shad (Table 3; Figure 7). CHLa concentrations in Shad tanks exceeded those measured in all other treatments at every level of nutrient addition. The presence of shad had the greatest influence on CHLa at the two lowest levels of nutrient addition ( $0,33 \%$ of ambient) where concentrations were $89 \pm 16$ and $113 \pm 34 \mu \mathrm{g} \mathrm{L}^{-1}$ (2-fold higher relative to Controls). At the two highest levels of nutrient addition (66 and 100\% of ambient), differences between Shad and Control treatments were smaller (3 and $30 \mu \mathrm{g} \mathrm{CHLa} \mathrm{L}{ }^{-1}$, respectively). Tanks with Rangia or Sediment exhibited similar CHLa concentrations to the Controls. The ANCOVA revealed that nutrient addition $(\mathrm{p}<$ $0.0001)$ and the presence of shad $(\mathrm{p}=0.01)$ were significant factors accounting for variation in CHLa, whereas differences between Control, Sediment and Rangia treatments were not significant (Table 4).

Zooplankton communities in the mesocosms were dominated by taxa found in the estuary (Brachionus calyciflorus, Eurytemora affinis nauplii and Bosmina longirostris). Rotifer densities declined during the 15-d experiment except in mesocosms with Rangia. In the presence of Rangia, rotifer densities increased from 276 ind $\mathrm{L}^{-1}$ (Day 0) to 448 and 1320 ind $\mathrm{L}^{-1}$ at the two highest levels of nutrient addition (66\% and 100\%, respectively). Copepod densities increased 
during the experiment, except in the presence of shad. Copepod starting densities were $11 \pm 3$ ind $\mathrm{L}^{-1}$; largest increases were observed in tanks with sediment $\left(109 \pm 21\right.$ ind $\left.\mathrm{L}^{-1}\right)$, followed by Controls $\left(44 \pm 25\right.$ ind $\left.\mathrm{L}^{-1}\right)$ and Rangia $\left(19 \pm 6\right.$ ind $\left.\mathrm{L}^{-1}\right)$. No copepods were found in mesocosms containing shad. Bosmina densities did not show consistent differences among mesocosms with or without consumers. Starting densities were $1.0 \pm 0.2$ ind $\mathrm{L}^{-1}$ and final densities averaged 13.5 \pm 4.0 ind $\mathrm{L}^{-1}$ (across all mesocosms). Estimated grazing rates in Sediment $\left(29 \pm 4 \% \mathrm{~d}^{-1}\right)$ and Rangia $\left(26 \pm 11 \% \mathrm{~d}^{-1}\right)$ treatments were higher relative to initial conditions $\left(13 \% \mathrm{~d}^{-1}\right)$ as increasing densities of copepods and Bosmina more than compensated for declines in rotifers. Grazing rates in mesocosms with shad were lower $\left(6 \pm 3 \% \mathrm{~d}^{-1}\right)$ in comparison to these treatments, and relative to the Control $\left(15 \pm 6 \% \mathrm{~d}^{-1}\right)$.

Microcystis gene copies and microcystin concentrations decreased in response to nutrient reductions in Control, Sediment and Rangia treatments. Highest toxin levels were observed at the highest rate of nutrient addition $(100 \%)$ and in the absence of consumers. From initial values of $\left(0.07 \mu \mathrm{g} \mathrm{MC} \mathrm{L}^{-1}\right.$; Table 3$)$ mesocosms without consumers reached final concentrations of 1.84 $\mu \mathrm{g} \mathrm{L}^{-1}$ (Control) and $3.25 \mu \mathrm{g} \mathrm{L}^{-1}$ (Sediment), whereas mesocosms with consumers did not exceed $0.60 \mu \mathrm{g} \mathrm{MC} \mathrm{L}^{-1}$. Lowest levels of microcystin were observed in mesocosms with Shad. The abundance of Microcystis genes varied by over 5 orders of magnitude with highest levels observed at highest nutrient additions in Control, Sediment and Rangia treatments. Lowest abundance of Microcystis was observed in tanks with Shad. Both nutrient enrichment and the presence of consumers were significant predictors of variation in microcystin and Microcystis (Table 4).

\section{Discussion}

Our findings suggest weak top-down effects of consumers via grazing and $\mathrm{N}$ recycling when considered in the context of other fluxes controlling CHLa and N in the tidal fresh James River. The combined grazing by zooplankton, benthic filter-feeders and fish was small $(3.1 \mu \mathrm{g}$ CHLa L $\mathrm{L}^{-1} \mathrm{~d}^{-1}$ ) corresponding to $15 \%$ of average daily CHLa production. Assigning error to this estimate of CHLa consumption is problematic given the difficulties in deriving propagated errors from multiple sources. Potential sources of error include estimation of algal contributions to diet, estimation of consumer abundance, particularly for fish, and uncertainty regarding gut turnover rates in fish. Zooplankton densities during the study period were lower than our 
previously published values for the James (Table 1). However, our estimates of zooplankton community grazing rates $(6.8 \pm 1.7 \%)$ were similar to those previously derived from direct measurements $(4.0 \pm 1.7 \%)$. Our use of literature estimates for zooplankton clearance rates from lakes likely overestimates grazing in turbid estuaries (Merrell and Stoecker 1998), but overall the results suggest that zooplankton densities in the James are too low to exert substantial grazing pressure on phytoplankton. A similar result was obtained for benthic filter-feeders. Our measured clearance rates for Rangia $\left(7.4 \pm 1.7 \mathrm{~L} \mathrm{ind}^{-1} \mathrm{~d}^{-1}\right)$ were lower than the median value ( $\left.\sim 20 \mathrm{~L}_{\text {ind }}^{-1} \mathrm{~d}^{-1}\right)$ used by Cerco and Noel (2010) to model effects of benthic filter-feeders on CHLa in the James. Our lower value may in part reflect reduced grazing rates when microcystin is present (Wood et al. 2014), but the very small contribution by Rangia to overall grazing rates (1.4 $\mu \mathrm{g} \mathrm{CHLa} \mathrm{L}^{-1} \mathrm{~d}^{-1}$ ) would not be appreciably affected by using the higher clearance rate. There is greater uncertainty in fish abundance estimates given variability in capture efficiency among various types of equipment. We did not consider capture efficiency in our estimation of abundance and therefore these estimates may be conservative. However, values for Blue Catfish density and Gizzard Shad biomass were within expected ranges for this and other systems (Table 1). The three fish samplings were conducted over a period of 12 months and provided similar estimates of abundance ( $\mathrm{CV}<20 \%$ for all species). These would not be representative of longer-term variability in fish abundance that might be associated with year-to-year variation in recruitment or survivorship (Cury et al. 2000). We consider the largest source of uncertainty in this analysis to be the gut turnover time for fish as we lack empirical data specific to this system. We therefore incorporated a 4-fold range of values to assess their effect on consumption rates. The results were robust in that CHLa ingestion by fish was low $\left(0.36 \mu \mathrm{g} \mathrm{L}^{-1} \mathrm{~d}^{-1}\right)$ even when using the highest rate of gut turnover in fish $\left(18 \mathrm{~d}^{-1}=1.3 \mathrm{~h}\right)$ and correcting for potential degradation of CHLa in gut materials.

High rates of phytoplankton production, in combination with low loss rates via grazing and advective transport, suggest that the bulk of phytoplankton production is lost to autotrophic and heterotrophic respiration within the study reach. This finding was supported by results showing that respiration supported by autochthonous production was equivalent to $74 \%$ of daily CHLa production. The autochthonous-supported fraction of ecosystem respiration was derived from a regression of R and NPP. Though statistical uncertainty in this estimate was small $(<10 \%)$ we lack empirical data to assess the validity of this method for allocating the proportion 
of ecosystem respiration supported by autochthonous vs. allochthonous inputs. However, our estimate of CHLa loss due to autotrophic and heterotrophic respiration, in combination with grazing and advective losses of CHLa showed good agreement (within 10\%) with CHLa production. Over a growing season, CHLa production by phytoplankton should balance losses due to decomposition, grazing and advection. Our results showing that these independent estimates of production and loss are in balance provides support for this approach to partitioning the fate of phytoplankton production. Furthermore, our prior work with algal bioassays has shown that $70-90 \%$ of autotrophic DIN uptake enters the DON pool within $48 \mathrm{~h}$, which suggests that the bulk of assimilated $\mathrm{N}$ is rapidly recycled (Wood and Bukaveckas 2014). Our findings are also consistent with studies of ecosystem metabolism showing that microbial respiration closely tracks production due to rapid decomposition of autochthonous organic matter (Staehr and Sand-Jenson 2007). Overall, these results suggest a rapid recycling of phytoplankton production, which may in part account for low export losses.

Although consumers accounted for a small fraction of CHLa losses, their importance in recycling $\mathrm{N}$ was somewhat greater, potentially contributing $25 \%$ of daily phytoplankton $\mathrm{N}$ demand. The disproportionate effect of consumers on $\mathrm{N}$ cycling vs. CHLa removal is attributed to the contribution of allochthonous organic matter to consumer-mediated $\mathrm{N}$ recycling. Based on C:CHLa ratios, we estimate that allochthonous sources contribute $60 \%$ of organic matter in estuarine seston, and $90 \%$ of organic matter in estuarine sediments. Though the allochthonous fraction has a low $\mathrm{N}$ content $(\mathrm{C}: \mathrm{N}=15)$ relative to autochthonous organic matter, consumer ingestion and excretion of this material would result in a high ratio of $\mathrm{N}$ recycled relative to algal biomass removed. This was most apparent in benthivorous fishes whose diet was low in CHLa but comparable to planktivores in $\mathrm{N}$ content. Because benthivorous fishes are important in the James (90\% of fish biomass), fish accounted for a greater proportion of grazer PON ingestion (37\%) than for CHLa (11\%). Estimates of $\mathrm{N}$ recycling by Gizzard Shad in the James based on PON ingestion $\left(0.0033-0.0150 \mathrm{mg} \mathrm{N} \mathrm{L}^{-1} \mathrm{~d}^{-1}\right)$ were similar to direct measurements of $\mathrm{N}$ excretion reported by Shostell and Bukaveckas (2004; mean $\left.=0.0025 \mathrm{mg} \mathrm{N} \mathrm{L}^{-1} \mathrm{~d}^{-1}\right)$ and Vanni et al. $\left(2006\right.$; range $\left.=0.0024-0.0375 \mathrm{mg} \mathrm{N} \mathrm{L}^{-1} \mathrm{~d}^{-1}\right)$ for Midwestern reservoirs. Despite the similarity in $\mathrm{N}$ recycling rates, the proportion of phytoplankton $\mathrm{N}$ demand potentially met by Gizzard Shad is much smaller in the James (1-5\%) in comparison with these other systems (Shostell and Bukaveckas $=43 \%$, Vanni et al. $2006=27-67 \%$ ). This is primarily due to higher 
levels of primary production and algal nitrogen demand in the James. These findings suggest that consumer effects, though weak, favor eutrophic conditions by recycling $\mathrm{N}$ from autochthonous and allochthonous organic matter, while removing relatively little phytoplankton biomass.

The finding that consumers enhance eutrophic conditions in the James was supported by results from a mesocosm experiment showing that one of the two consumers tested (shad) had a positive effect on CHLa. In the presence of shad, zooplankton (principally copepods) were removed resulting in reduced grazing pressure and higher phytoplankton biomass. Grazer effects were observed at all levels of nutrient addition but were greatest in mesocosms receiving the smallest nutrient additions. The positive response of Microcystis to nutrient loading supports previous studies which suggest that Microcystis is more common under eutrophic conditions (Moisander et al. 2009, Poste et al. 2011). Interestingly, Microcystis gene copies and microcystin concentrations were lower in the presence of shad, with largest differences (relative to Controls) observed at the highest nutrient loading rates. Given that CHLa levels were elevated in tanks with shad, toxin production normalized to CHLa showed even larger differences and suggest negative selection pressure on toxic cyanobacteria in the presence of shad. This result was unexpected given other studies that have suggested Microcystis can transverse the gut of fish and potentially benefit from gut passage by assimilating nutrients (Friedland et al. 2005, Jančula et al. 2008). The negative effect of shad upon Microcystis may be due to a loss of competitive advantage for toxic strains of Microcystis with reduced grazing pressure from zooplankton.

Results from stable isotope analysis showed that estuarine seston collected during high CHLa conditions was depleted in $\delta^{13} \mathrm{C}$ relative to riverine seston collected during periods of high terrestrial organic matter inputs. $\delta^{13} \mathrm{C}$ of zooplankton and planktivorous fish matched expected values for consumers utilizing autochthonous organic matter sources, whereas Rangia and benthivorous fish exhibited greater dependency on allochthonous inputs. These findings were based on consumer isotopic signatures during summer when autochthonous contributions were likely maximal. Other studies have demonstrated the importance of allochthony in systems with high watershed loading factors (e.g., rivers and estuaries) and this has been attributed in part to constraints on autotrophic production imposed by non-algal turbidity (Hoffman et al. 2007, Zeug and Winemiller 2008, Roach 2013). Our results, for a system with high phytoplankton biomass and dominated by nutritious forms of algae (greens and diatoms), suggest that terrestrial support 
of food webs can be important even in systems with high levels of autochthonous production. One factor contributing to the high degree of allochthony in the James is the importance of benthivory with juvenile Blue Catfish, adult Gizzard Shad and bivalves (Rangia) primarily consuming sedimented material that was largely comprised of terrestrial organic matter. As these consumers dominate metazoan biomass, they drive the dependence on allochthony. A second factor is that among pelagic-feeding consumers, allochthonous materials constitute a sizeable proportion of their potential food resources, even during periods of low external inputs, owing to tidal re-suspension of sediment. In a system where a large proportion of seston is comprised of allochthonous material, obtaining an algal-based diet may be difficult

We consider these findings in the context of three long-standing questions in aquatic ecology: How do ecosystems respond to nutrient inputs? What is the strength of consumer regulation of primary producers? How important are allochthonous inputs to food webs? We contend that the answer to the first two questions is dependent on the third. Specifically, we argue that the presence of allochthonous organic matter weakens consumer control and favors a net positive effect of grazing on phytoplankton. The 'subsidy hypothesis' suggests that allochthonous inputs enhance secondary production and strengthen consumer control. We propose an alternative view, the 'subsidy dilution hypothesis', whereby the presence of allochthonous materials diminishes the quality of food resources and thereby limits consumer exploitation. Prior work has shown that consumer utilization of primary production is higher in aquatic vs. terrestrial ecosystems due to superior nutritional quality of algae relative to terrestrial plants (Cyr and Pace 1992; Brett et al. 2009; Cebrian 2004). High rates of consumer exploitation (e.g., approaching 100\%) are observed in pelagic food webs where autochthonous materials dominate food resources (Lampert et al. 1986; Luecke et al. 1990). Where allochthonous materials dominate, we propose that diminished food quality constrains consumer utilization of food resources thereby weakening top-down effects. Further, we suggest that phytoplankton benefit from the presence of allochthonous materials in the diets of consumers due to the higher rate of nutrient regeneration per unit of algal biomass consumed. Among pelagic food webs, these effects may be most apparent in estuaries where tidal forces maintain allochthonous materials in suspension. However, subsidy dilution effects are also relevant to systems where benthivory is important and sediments are largely comprised of terrestrial organic matter (e.g., shallow lakes, floodplain rivers and coastal lagoons). Taking a broader view, we hypothesize 
that the influence of subsidies on consumer control of primary production will depend on the difference in food quality between donor and recipient systems. In aquatic systems, where allochthonous inputs are of inferior quality, we predict that they will weaken consumer effects, whereas in terrestrial systems, allochthonous inputs of aquatic origin (e.g., seaweed inputs to islands) enhance the quantity and quality of food resources for consumers, leading to stronger top-down effects (Polis and Hurd 1996).

Lastly, as the impetus for this study was to assess the role of consumers in influencing the trophic state of the James, we conclude with a consideration of implications for nutrient management. Our findings suggest that the sensitivity of this system to external nutrient loads is attributable in part to weak consumer control because grazing removes only a small fraction of phytoplankton production. We hypothesize that consumer exploitation of autochthonous production is constrained by the presence of terrestrially-derived organic matter, which may reflect a legacy of watershed disturbance and sediment transport. Historical changes in fish communities of the James may also contribute to greater food-web dependence on allochthony following the decline of anadromous planktivorous clupeids and introduction of benthivores (Blue and Channel Catfish; Garman and Macko 1998; Schloesser et al. 2011). Recent reductions in local point source inputs to the James have elicited signs of recovery including lower nutrient concentrations in summer and greater nutrient limitation of phytoplankton, but have not brought about a reduction in CHLa (Wood and Bukaveckas 2014). Mass balance analysis suggests that a large fraction of algal nutrient demand is met by internal recycling (Bukaveckas and Isenberg 2013), and this finding is supported by the results of the present study showing that the bulk of phytoplankton production is recycled. Results from mesocosm experiments suggest that the importance of consumer-mediated nutrient recycling will increase as external inputs decline, thus potentially delaying recovery.

\section{Acknowledgements}

This research was partially supported by funding from the Virginia Department of Environmental Quality and the City of Richmond Department of Public Utilities. The views presented herein are not necessarily those of the sponsoring agencies. Joe Wood was supported by a Fellowship from the VCU Graduate Program in Integrative Life Sciences. David Elliott was supported by an NSF post-doctoral fellowship. This paper is contribution \#66 to the VCU Rice Rivers Center. 


\section{References}

Atkinson, C. L., J. F. Kelly, and C. C. Vaughn 2014. Tracing consumer-derived nitrogen in riverine food webs. Ecosystems 17: 485-496.

Bogdan, K. G., and J. J. Gilbert 1984. Body size and food size in freshwater zooplankton. Proceedings of the National Academy of Sciences USA 81: 6427-6431.

Borer, E.T., E.W. Seabloom, J.B. Shurin, K.E. Anderson, C.A. Blanchette, B. Broitman et al. 2005. What determines the strength of trophic cascades? Ecology 86: 528-537.

Boynton. W.R, C.L.S. Hodgkins, C.A. O’Leary, E.M. Baily, A.R. Bayard and L.A. Wainger. 2013. Multi-decade responses of a tidal creek system to nutrient load reductions: Mattawoman Creek, Maryland USA. Estuaries and Coasts 37:111-127.

Brett, M. T., M. Kainz, S. Taipale, and H. Seshan 2009. Phytoplankton, not allochthonous carbon, sustains herbivorous zooplankton production. Proceedings of the National Academy of Sciences USA 106: 21197-21201.

Bukaveckas, P. A., L. E. Barry, M. J. Beckwith, V. David, and B. Lederer 2011. Factors determining the location of the chlorophyll maximum and the fate of algal production within the tidal freshwater James River. Estuaries and Coasts 34: 569-582.

Bukaveckas, P. A., and W. N. Isenberg 2013. Loading, transformation and retention of nitrogen and phosphorus in the tidal freshwater James River (Virginia). Estuaries and Coasts 36: 1219-1236.

Caffrey, J. M. 2003. Production, respiration and net ecosystem metabolism in U.S. estuaries. Environmental Monitoring and Assessment 81: 207-219.

Caffrey, J. M. 2004. Factors controlling net ecosystem metabolism in U.S. estuaries. Estuaries 27: 90-101.

Caraco, N. F., J. J. Cole, and D. L. Strayer 2006. Top-down control from the bottom: Regulation of eutrophication in a large river by benthic grazing. Limnology and Oceanography 51: 664-670.

Carstensen, J., M. Sanchez-Camacho, C. M. Duarte, D. Krause-Jensen, and N. Marba 2011. Connecting the dots: Responses of coastal ecosystems to changing nutrient concentrations. Environmental Science and Technology 45: 9122-9132.

Cebrian, J. 2004. Role of first-order consumers in ecosystem carbon flow. Ecology Letters 7: 232-240.

Cerco, C. F., and M. R. Noel 2010. Monitoring, modeling and management impacts of bivalve filter feeders in the oligohaline and tidal fresh regions of the Chesapeake Bay system. Ecological Modelling 221: 1054-1064.

Chick, J. H., A. P. Levchuk, K. A. Medley, and J. E. Havel 2010. Underestimation of rotifer abundance a much greater problem than previously appreciated. Limnology and Oceanography: Methods 8: 79-87. 
Coughlan, J. 1969. The estimation of filtering rate from the clearance of suspensions. Marine Biology 2: 356-358.

Cole, J. and C. Solomon. 2012. Terrestrial support of zebra mussels and the Hudson River food web: A multi-isotope, Bayesian analysis. Limnology and Oceanography 57, 2 1802-1815.

Cury, P., A. Bakun, R. J. M. Crawford, A. Jarre, R. A. Quinones, L. J. Shannon, and H. M. Verheye 2000. Small pelagics in upwelling systems: patterns of interaction and structural changes in 'wasp-waist' ecosystems. ICES Journal of Marine Science 57: 603-618.

Cyr, H., and M. L. Pace 1992. Grazing by zooplankton and its relationship to community structure. Canadian Journal of Fisheries and Aquatic Sciences 49: 1455-1465.

Dias, E., P. Morais, C. Antunes, and J. C. Hoffman. 2014. Linking terrestrial and benthic estuarine ecosystems: Organic matter sources supporting the high secondary production of a non-indigenous bivalve. Biological Invasions 16: 2163-79.

del Giorgio, P. A., and R. H. Peters 1994. Patterns in planktonic P:R ratios in lakes: Influence of lake trophy and dissolved organic carbon. Limnology and Oceanography 39: 772-787.

Duarte, C. M., D. J. Conley, J. Carstensen, and M. Sanchez-Camacho 2009. Return to Neverland: Shifting baselines affect eutrophication restoration targets. Estuaries and Coasts 32: 29-36.

Elliott, D. T., and K.W. Tang. 2011. Spatial and temporal distributions of live and dead copepods in the lower Chesapeake Bay (Virginia, USA). Estuaries and Coasts, 34: 1039-1048.

Friedland, K. D., D. W. Ahrenholz, and L. W. Haas 2005. Viable gut passage of cyanobacteria through the filter-feeding fish Atlantic menhaden, Brevoortia tyrannus. Journal of Plankton Research 27: 715-718.

Garman, G. C., and S. A. Macko 1998. Contribution of marine-derived organic matter to an Atlantic coast, tidal stream by anadromous clupeid fishes. Journal of the North American Benthological Society 17: 277-285.

Gerritsen, J., A. F. Holland, and D. E. Irvine 1994. Suspension-feeding bivalves and the fate of primary production: an estuarine model applied to Chesapeake Bay. Estuaries 17: 403416.

Greening, H., and Janicki, A. 2006. Toward reversal of eutrophic conditions in a subtropical estuary: water quality and seagrass response to nitrogen loading reductions in Tampa Bay, Florida, USA. Environmental Management, 38: 163-178.

Greening, H. S., Cross, L. M., and Sherwood, E. T. 2011. A multiscale approach to seagrass recovery in Tampa Bay, Florida. Ecological Restoration, 29: 82-93.

Hairston, N.G., F.E. Smith and L.B. Slobodkin. 1960. Community structure, population control and competition. American Naturalist 94: 421-425.

Hall, S. R., J.B. Shurin, S. Diehl and R.M. Nisbet. 2007. Food quality, nutrient limitation of secondary production and the strength of trophic cascades. Oikos 116: 1128-1143. 
Hoffman, J. C., D. A. Bronk, and J. E. Olney 2007. Contribution of allochthonous carbon to American shad production in the Mattaponi River, Virginia, using stable isotopes. Estuaries and Coasts 30: 1034-1048.

Jančula, D., M. Míkovcov, Z. Adámek, and B. Maršálek. 2008. Changes in the photosynthetic activity of Microcystis colonies after gut passage through Nile tilapia (Oreochromis niloticus) and silver carp (Hypophthalmichthys molitrix). Aquaculture Research 39: 311314.

Kimmerer, W. J., and J. K. Thompson 2014. Phytoplankton growth balanced by clam and zooplankton grazing and net transport into the low salinity zone of the San Francisco Estuary. Estuaries and Coasts 37: 1202-1218.

Lampert, W., W. Fleckner, H. Rai and B.E. Taylor. 1986. Phytoplankton control by grazing zooplankton: A study on the Spring Clearwater phase. Limnology and Oceanography 31:478-490.

Leroux, S. J., and M. Loreau 2010. Consumer-mediated recycling and cascading trophic interactions. Ecology 91: 2162-2171.

Lucas, L. V., and J. K. Thompson 2012. Changing restoration rules: Exotic bivalves interact with residence time and depth to control phytoplankton productivity. Ecosphere 3: 117.

Luecke, C., M. J. VanniI, J. J. Magnuson, J. F. Kitchell, and P. J. Jacobson. 1990. Seasonal regulation of Daphnia populations by planktivorous fish: Implications for the clear water phase. Limnology and Oceanography 35: 1718-1733.

Marino, R., and R. W. Howarth 1993. Atmospheric oxygen exchange in the Hudson River: Dome measurements and comparison with other natural waters. Estuaries 16: 433-445.

Merrell, J. R., and D. K. Stoecker. 1998. Differential grazing on protozoan microplankton by developmental stages of the Calanoid copepod Eurytemora Affinis Poppe. Journal of Plankton Research 20: 289-304.

Moisander, P. H.; Ochiai, M.; Lincoff, A. 2009. Nutrient limitation of Microcystis aeruginosa in northern California Klamath River reservoirs. Harmful Algae 8: 889-897.

Oksanen, L., S.D. Fretwell, J. Arruda and P. Niemela. 1981. Exploitation ecosystems in gradients of primary productivity. American Naturalist 118: 240-261.

Orth, R. J., Williams, M. R., Marion, S. R., Wilcox, D. J., Carruthers, T. J. B., Moore, K. A., Batiuk, R. A. 2010. Long-term trends in submersed aquatic vegetation (SAV) in Chesapeake Bay, USA, related to water quality. Estuaries and Coasts, 33: 1144-1163.

Peierls, B. L., N. S. Hall, and H. W. Paerl 2012. Non-monotonic responses of phytoplankton biomass accumulation to hydrologic variability: A comparison of two Coastal Plain North Carolina estuaries. Estuaries and Coasts 35: 1376-1392.

Polis, G. A., and S. D. Hurd 1996. Linking marine and terrestrial food webs: Allochthonous input from the ocean supports high secondary productivity on small islands and coastal land communities. American Naturalist 147: 396-423.

Poste, A. E., R. E. Hecky, and S. J. Guilidford 2011. Evaluating microcystin exposure risk through fish consumption. Environmental Science and Technology 45: 5806-5811. 
Roach, K. A. 2013. Environmental factors affecting incorporation of terrestrial material into large river food webs. Freshwater Science 32: 283-298.

Schaus, M. H., and M. J. Vanni. 2000. Effects of Gizzard Shad on phytoplankton and nutrient dynamics: Role of sediment feeding and fish size. Ecology 81: 1701-1719

Schloesser, R. W., M. C. Fabrizio, R. J. Latour, G. C. Garman, R. S. Greenlee, M. Groves, and J. Gartland 2011. Ecological role of blue catfish in Chesapeake Bay communities and implications for management. American Fisheries Society Symposium 77: 369-382.

Schmitz, O. J., J. H. Grabowski, B. L. Peckarsky, E. L. Preisser, G. C. Trussell, and J. R. Vonesh 2008. From individuals to ecosystem function: toward an integration of evolutionary and ecosystem ecology. Ecology 89: 2436-2445.

Shepherd, W.C. and E.L. Mills. 1996. Diel feeding, daily food intake, and Daphnia consumption by age-0 gizzard shad in Oneida Lake, New York. Transaction of the American Fisheries Society 125:411-421.

Shostell, J., and P. A. Bukaveckas 2004. Seasonal and interannual variation in nutrient fluxes from tributary inputs, consumer recycling and algal growth in a eutrophic river impoundment. Aquatic Ecology 38: 359-373.

Sierszen, M. E., and T. M. Frost 1990. Effects of an experimental lake acidification on zooplankton feeding rates and selectivity. Canadian Journal of Fisheries and Aquatic Sciences 47: 772-779.

Staehr, P. A., and K. Sand-Jensen 2007. Temporal dynamics and regulation of lake metabolism. Limnology and Oceanography 52: 108-120.

Sturdivant, S. K., R. J. Diaz, R. Llanso, and D. M. Dauer 2014. Relationship between hypoxia and macrobenthic production in Chesapeake Bay. Estuaries and Coasts 37: 1219-1232.

Vanni, M. J., K. K. Arend, M. T. Bremigan, D. B. Bunnell, J. E. Garvey, M. J. Gonzalez, W. H. Renwick, P. A. Soranno, and R. A. Stein 2005. Linking landscapes and food webs: Effects of omnivorous fish and watersheds on reservoir ecosystems. BioScience 55: 155167.

Vanni, M. J., A. M. Bowling, E. M. Dickman, R. S. Hale, K. A. Higgins, M. J. Horgan, L. B. Knoll, W. H. Renwick, and R. A. Stein 2006. Nutrient cycling by fish supports relatively more primary production as lake productivity increases. Ecology 87: 1696-1709.

Vannote, R. L., G. W. Minshall, K. W. Cummins, J. R. Sedell, and C. E. Cushing 1980. The river continuum concept. Canadian Journal of Fisheries and Aquatic Sciences 37: 130-137.

Verdonschot, P. F. M., B. M. Spears, C. K. Feld, S. Brucet, H. Keizer-Vlek, A. Borja, M. Elliott, M. Kernan, and R. K. Johnson. 2013. A comparative review of recovery processes in rivers, lakes, estuarine and coastal waters. Hydrobiologia 704: 453-474.

Wong, W. H., N. N. Rabalais, and R. E. Turner 2010. Abundance and ecological significance of the clam Rangia cuneata (Sowerby, 1831) in the upper Barataria Estuary (Louisiana, USA). Hydrobiologia 651: 305-315. 
Wood, J. D., and P. A. Bukaveckas 2014. Increasing severity of phytoplankton nutrient limitation following reductions in point source inputs to the tidal freshwater segment of the James River Estuary. Estuaries and Coasts 37: 1188-1201.

Wood, J. D., R. B. Franklin, G. C. Garman, S. P. McInich, A. J. Porter, and P. A. Bukaveckas 2014. Exposure to the cyanotoxin microcystin arising from inter-specific differences in feeding habits among fish and shellfish from the James River Estuary, Virginia. Environmental Science and Technology 48: 5194-5202.

Zeug, S. C., and K. O. Winemiller 2008. Evidence supporting the importance of terrestrial carbon in a large-river food web. Ecology 89: 1733-1743. 
Table 1. Data used to derive consumption rates by zooplankton, benthic filter-feeders (Rangia) and fish in the James River Estuary (VA, USA) with comparison values from this and other systems. Standard errors included where available.

\begin{tabular}{|c|c|c|c|c|}
\hline & This Study & Comparison & Site & Source \\
\hline \multicolumn{5}{|l|}{ Zooplankton } \\
\hline \multicolumn{5}{|l|}{ abundance (ind $\mathrm{L}^{-1}$ ) } \\
\hline rotifers & $154 \pm 25$ & $333 \pm 67$ & James & Bukaveckas et al. 2011 \\
\hline Bosmina & $1.0 \pm 0.2$ & $19 \pm 5$ & James & Bukaveckas et al. 2011 \\
\hline Eurytemora & $0.7 \pm 0.2$ & $2.2 \pm 0.3$ & James & Bukaveckas et al. 2011 \\
\hline Nauplii & $1.4 \pm 0.3$ & $73 \pm 9$ & James & Bukaveckas et al. 2011 \\
\hline Community Grazing $\left(\% \mathrm{~d}^{-1}\right)$ & $6.8 \pm 1.7 \%$ & $4.0 \pm 0.4 \%$ & James & Bukaveckas et al. 2011 \\
\hline \multicolumn{5}{|l|}{ Rangia } \\
\hline abundance (ind $\mathrm{m}^{-3}$ ) & NA & $10 \pm 2$ & James & CBP Benthic Monitoring \\
\hline clearance $\left(\mathrm{Lind}^{-1} \mathrm{~d}^{-1}\right)$ & $7.4 \pm 1.7$ & 19.8 & $\begin{array}{c}\text { Chesapeake } \\
\text { Bay }\end{array}$ & Cerco \& Noel 2010 \\
\hline \multicolumn{5}{|l|}{ Fish } \\
\hline \multicolumn{5}{|l|}{ abundance } \\
\hline Blue Catfish (ind ha ${ }^{-1}$ ) & 511 & 681 & James & VA Dept. Game \& Fish \\
\hline Gizzard Shad $\left(\mathrm{kg} \mathrm{ha}^{-1}\right)$ & 117 & $20-400$ & $\begin{array}{l}\text { Midwest } \\
\text { reservoirs }\end{array}$ & $\begin{array}{l}\text { Shostell \& Bukaveckas } \\
\text { 2004; Vanni et al. } 2005\end{array}$ \\
\hline gut turnover $\left(\mathrm{d}^{-1}\right)$ & NA & $4-18$ & Oneida Lake & Shepherd \& Mills 1996 \\
\hline
\end{tabular}


Table 2. Isotopic signatures (with standard error) of seston, sediment and dominant consumers for the tidal fresh James River (VA, USA). Biomass estimates for consumers are based on abundance data collected in this study (YOY = young of the year).

\begin{tabular}{lcccc}
\hline \multicolumn{1}{c}{ Sample } & $\mathrm{N}$ & ${ }^{13} \mathrm{C} \%$ & ${ }^{15} \mathrm{~N} \% \mathrm{o}$ & $\begin{array}{c}\text { Biomass } \\
\left(\mathrm{g} \mathrm{DW} \mathrm{m}^{-3}\right)\end{array}$ \\
\hline \hline Riverine Seston & 9 & $-26.8 \pm 0.1$ & $2.0 \pm 0.4$ & \\
Estuarine Seston & 13 & $-29.0 \pm 0.2$ & $6.2 \pm 0.2$ & \\
Sediment & 18 & $-26.7 \pm 0.1$ & $5.4 \pm 0.1$ & \\
Zooplankton & 6 & $-29.3 \pm 0.4$ & $10.1 \pm 0.5$ & $0.2-0.8$ \\
Rangia & 30 & $-25.8 \pm 0.2$ & $11.6 \pm 0.1$ & 2.30 \\
Blue Crab & 20 & $-25.2 \pm 0.3$ & $11.7 \pm 0.3$ & - \\
Threadfin Shad & 29 & $-28.2 \pm 0.2$ & $11.2 \pm 0.3$ & 0.06 \\
Menhaden & 15 & $-27.8 \pm 0.4$ & $12.6 \pm 0.3$ & 0.02 \\
YOY Gizzard Shad & 28 & $-27.3 \pm 0.2$ & $10.6 \pm 0.4$ & 0.03 \\
Adult Gizzard Shad & 28 & $-25.1 \pm 0.3$ & $11.9 \pm 0.3$ & 0.98 \\
Blue Catfish & 61 & $-25.7 \pm 0.1$ & $14.0 \pm 0.1$ & 0.37 \\
\hline
\end{tabular}


Table 3. Results from an outdoor mesocosm experiment examining the effects of consumers (Rangia, Shad) on CHLa, nutrients, zooplankton, Microcystin (MC) and Microcystis gene copies (Mic) along a nutrient gradient. Data are means $\pm \mathrm{SE}$ (CHLa) or final (nutrients, zooplankton, MC, Mic) values for the 15-day experiment.

\begin{tabular}{|c|c|c|c|c|c|c|c|c|c|c|c|c|c|c|}
\hline $\begin{array}{l}\text { Loading Rate } \\
\text { (\% Ambient) }\end{array}$ & Treatment & $\begin{array}{l}\mathrm{CHLa} \\
\mu \mathrm{g} \mathrm{L}^{-1} \\
\end{array}$ & $\begin{array}{c}\mathrm{NO}_{\mathrm{x}} \\
\mathrm{mg} \mathrm{L}^{-1}\end{array}$ & $\begin{array}{c}\mathrm{NH}_{4} \\
\mathrm{mg} \mathrm{L}^{-1} \\
\end{array}$ & $\begin{array}{c}\mathrm{DIN} \\
\mathrm{mg} \mathrm{L}^{-1}\end{array}$ & $\begin{array}{c}\mathrm{TN} \\
\mathrm{mg} \mathrm{L}^{-1}\end{array}$ & $\begin{array}{c}\mathrm{PO}_{4} \\
\mathrm{mg} \mathrm{L}^{-1}\end{array}$ & $\begin{array}{c}\mathrm{TP} \\
\mathrm{mg} \mathrm{L}^{-1} \\
\end{array}$ & $\begin{array}{l}\text { Rotifers } \\
\text { ind } L^{-1}\end{array}$ & $\begin{array}{l}\text { Copepods } \\
\text { ind } L^{-1}\end{array}$ & $\begin{array}{c}\text { Cladocerans } \\
\text { ind } \mathrm{L}^{-1} \\
\end{array}$ & $\begin{array}{c}\mathrm{MC} \\
\mu \mathrm{g} \mathrm{L}^{-1} \\
\end{array}$ & $\begin{array}{c}\text { Mic } 10^{3} \\
\text { copies } \mathrm{mL}^{-1}\end{array}$ & $\begin{array}{l}\text { Nutrinet Limitation } \\
\text { Effect Size }\left(\mathrm{d}^{-1}\right)\end{array}$ \\
\hline Initial & $\mathrm{N} / \mathrm{A}$ & $3252.6 \pm 2.8$ & 0.10 & 0.02 & 0.12 & 0.58 & 0.04 & 0.04 & 276 & 11 & 1 & 0.07 & 1.9 & nd \\
\hline \multirow[t]{4}{*}{$0 \%$} & Control & $32.0 \pm 18.3$ & 0.00 & 0.01 & 0.01 & 0.35 & 0.03 & 0.01 & 26 & 8 & 2 & 0.08 & 0.0 & 2.26 \\
\hline & Rangia & $17.2 \pm 4.7$ & 0.00 & 0.03 & 0.19 & 0.58 & 0.06 & 0.03 & 19 & 2 & 8 & 0.04 & 0.0 & 0.03 \\
\hline & Shad & $89.0 \pm 16.2$ & 0.10 & 0.02 & 0.19 & 0.77 & 0.05 & 0.06 & 25 & 0 & 2 & 0.18 & 0.2 & 0.68 \\
\hline & Sediment & $16.5 \pm 6.3$ & 0.60 & 0.03 & 0.29 & 0.45 & 0.08 & 0.01 & 47 & 39 & 5 & 0.00 & 0.2 & 0.26 \\
\hline \multirow[t]{4}{*}{$33 \%$} & Control & $46.1 \pm 11.6$ & 0.10 & 0.09 & 0.04 & 0.48 & 0.08 & 0.12 & 42 & 5 & 12 & 0.39 & 14.6 & 1.40 \\
\hline & Rangia & $79.5 \pm 21.3$ & 0.24 & 0.29 & 0.53 & 1.03 & 0.13 & 0.18 & 128 & 16 & 50 & 0.19 & 1.4 & nd \\
\hline & Shad & $113.0 \pm 34.3$ & 0.66 & 0.20 & 0.60 & 1.08 & 0.18 & 0.14 & 27 & 0 & 37 & 0.16 & 0.0 & nd \\
\hline & Sediment & $94.5 \pm 15.0$ & 1.20 & 0.13 & 0.15 & 0.60 & 0.09 & 0.09 & 60 & 50 & 45 & 0.33 & 0.7 & nd \\
\hline \multirow[t]{4}{*}{$67 \%$} & Control & $96.1 \pm 18.7$ & 0.12 & 0.07 & 0.12 & 0.88 & 0.17 & 0.28 & 112 & 59 & 16 & 0.52 & 94.5 & 0.66 \\
\hline & Rangia & $88.0 \pm 51.7$ & 0.54 & 0.06 & 0.86 & 1.67 & 0.26 & 0.41 & 448 & 10 & 12 & 0.24 & 161.6 & nd \\
\hline & Shad & $99.9 \pm 24.0$ & 0.79 & 0.10 & 0.89 & 1.92 & 0.20 & 0.33 & 41 & 0 & 2 & 0.07 & 0.7 & nd \\
\hline & Sediment & $77.5 \pm 23.6$ & 1.37 & 0.06 & 0.48 & 1.13 & 0.18 & 0.22 & 324 & 44 & 2 & 0.47 & 32.4 & nd \\
\hline \multirow[t]{4}{*}{$100 \%$} & Control & $101.0 \pm 12.6$ & 0.26 & 0.03 & 0.63 & 1.59 & 0.31 & 0.53 & 245 & 15 & 13 & 1.84 & 270.3 & 0.08 \\
\hline & Rangia & $108.9 \pm 28.2$ & 0.14 & 0.01 & 1.33 & 2.28 & 0.41 & 0.61 & 1320 & 10 & 12 & 0.55 & 124.0 & nd \\
\hline & Shad & $131.1 \pm 17.3$ & 0.38 & 0.10 & 1.43 & 2.57 & 0.33 & 0.60 & 320 & 0 & 4 & 0.08 & 0.1 & 0.00 \\
\hline & Sediment & $76.1 \pm 8.6$ & 0.95 & 0.02 & 0.97 & 2.13 & 0.24 & 0.37 & 125 & 86 & 0 & 3.25 & 13.6 & 0.27 \\
\hline
\end{tabular}


Table 4. Analysis of covariance for a mesocosm experiment in which the presence (Rangia, Shad) and absence (Control, Sediment) of consumers was tested along a nutrient gradient $(0,33$, 66 and $100 \%$ of ambient). MC denotes Microcystin; Microcystis is based on gene copies. Probabilities denote the effects of nutrients, grazers and their interaction term. Letters indicate statistically significant differences among treatments.

\begin{tabular}{cccccccc}
\hline Parameter & Nutrient & \multicolumn{4}{c}{ Grazer Effect } & \multicolumn{2}{c}{ Interaction } \\
& $\mathrm{p}$ & Control & Sediment & Rangia & Shad & $\mathrm{p}$ & $\mathrm{p}$ \\
\hline \hline $\mathrm{CHLa}$ & $<0.0001$ & $\mathrm{~b}$ & $\mathrm{~b}$ & $\mathrm{~b}$ & $\mathrm{a}$ & 0.010 & $\mathrm{~ns}$ \\
$\mathrm{NH}_{4}$ & $\mathrm{~ns}$ & $\mathrm{~b}$ & $\mathrm{ab}$ & $\mathrm{a}$ & $\mathrm{ab}$ & 0.027 & $\mathrm{~ns}$ \\
$\mathrm{NO}_{\mathrm{x}}$ & $<0.0001$ & $\mathrm{~b}$ & $\mathrm{ab}$ & $\mathrm{a}$ & $\mathrm{a}$ & 0.016 & $\mathrm{~ns}$ \\
$\mathrm{DIN}$ & $<0.0001$ & $\mathrm{~b}$ & $\mathrm{ab}$ & $\mathrm{a}$ & $\mathrm{a}$ & 0.003 & $\mathrm{~ns}$ \\
$\mathrm{TN}$ & $<0.0001$ & $\mathrm{c}$ & $\mathrm{bc}$ & $\mathrm{ab}$ & $\mathrm{a}$ & 0.003 & $\mathrm{~ns}$ \\
$\mathrm{PO}_{4}$ & $<0.0001$ & $\mathrm{ab}$ & $\mathrm{b}$ & $\mathrm{a}$ & $\mathrm{ab}$ & 0.031 & $\mathrm{~ns}$ \\
$\mathrm{TP}$ & $<0.0001$ & $\mathrm{~b}$ & $\mathrm{ab}$ & $\mathrm{a}$ & $\mathrm{a}$ & 0.013 & $\mathrm{~ns}$ \\
rotifer & 0.0025 & $\mathrm{~b}$ & $\mathrm{~b}$ & $\mathrm{a}$ & $\mathrm{ab}$ & 0.005 & 0.003 \\
copepod & $\mathrm{ns}$ & $\mathrm{ab}$ & $\mathrm{a}$ & $\mathrm{b}$ & $\mathrm{b}$ & 0.002 & $\mathrm{~ns}$ \\
cladoceran & $\mathrm{ns}$ & $\mathrm{a}$ & $\mathrm{a}$ & $\mathrm{a}$ & $\mathrm{a}$ & $\mathrm{ns}$ & $\mathrm{ns}$ \\
MC & 0.009 & $\mathrm{ab}$ & $\mathrm{a}$ & $\mathrm{ab}$ & $\mathrm{b}$ & 0.023 & $\mathrm{~ns}$ \\
Microcystis & 0.004 & $\mathrm{a}$ & $\mathrm{ab}$ & $\mathrm{ab}$ & $\mathrm{b}$ & 0.032 & 0.029 \\
\hline
\end{tabular}


Figure 1. Map of the tidal freshwater region of the James River Estuary (VA, USA) showing weekly water quality monitoring stations, a continuous water quality monitoring site (Rice Pier), and fish sampling sites.
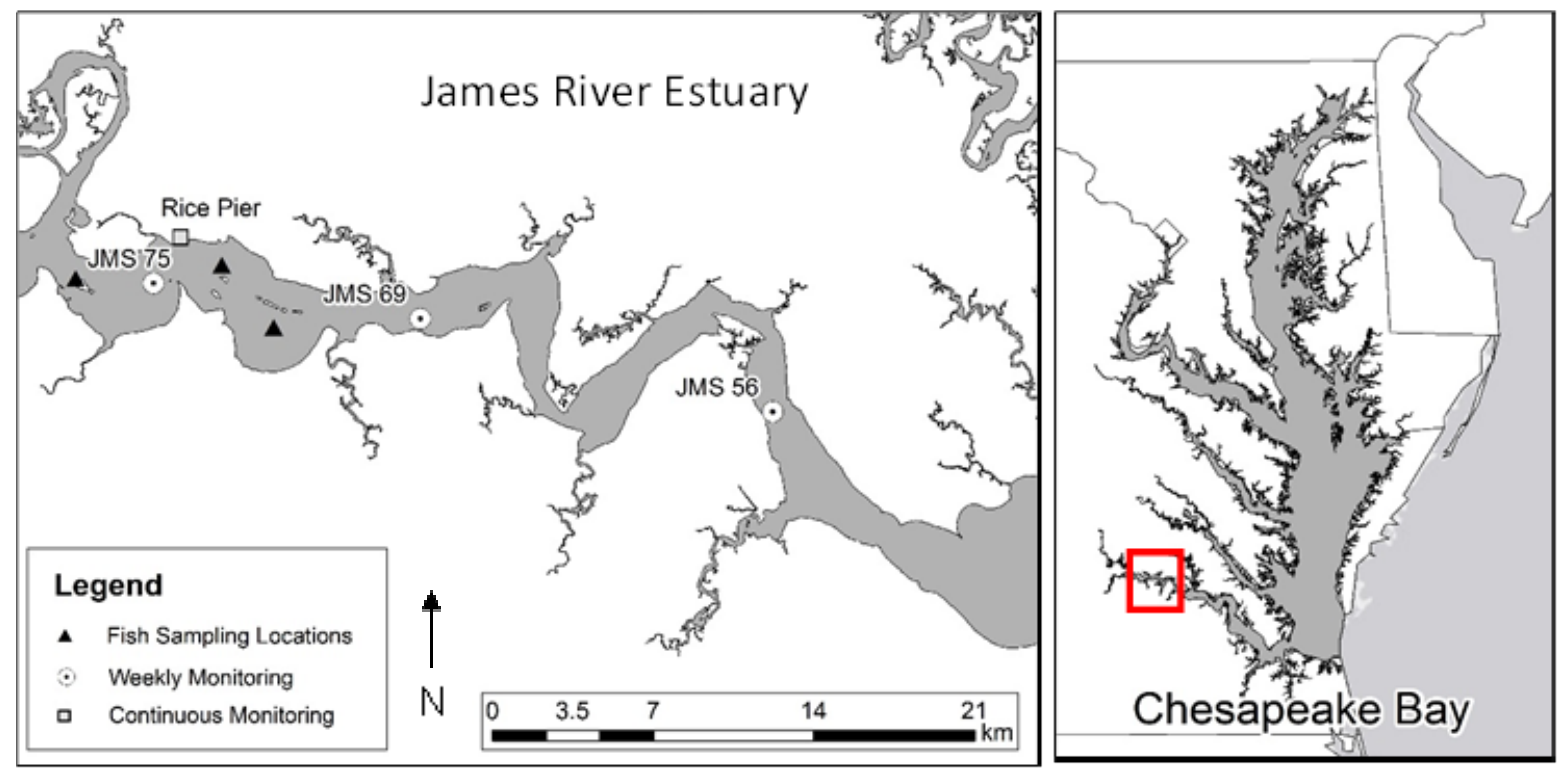

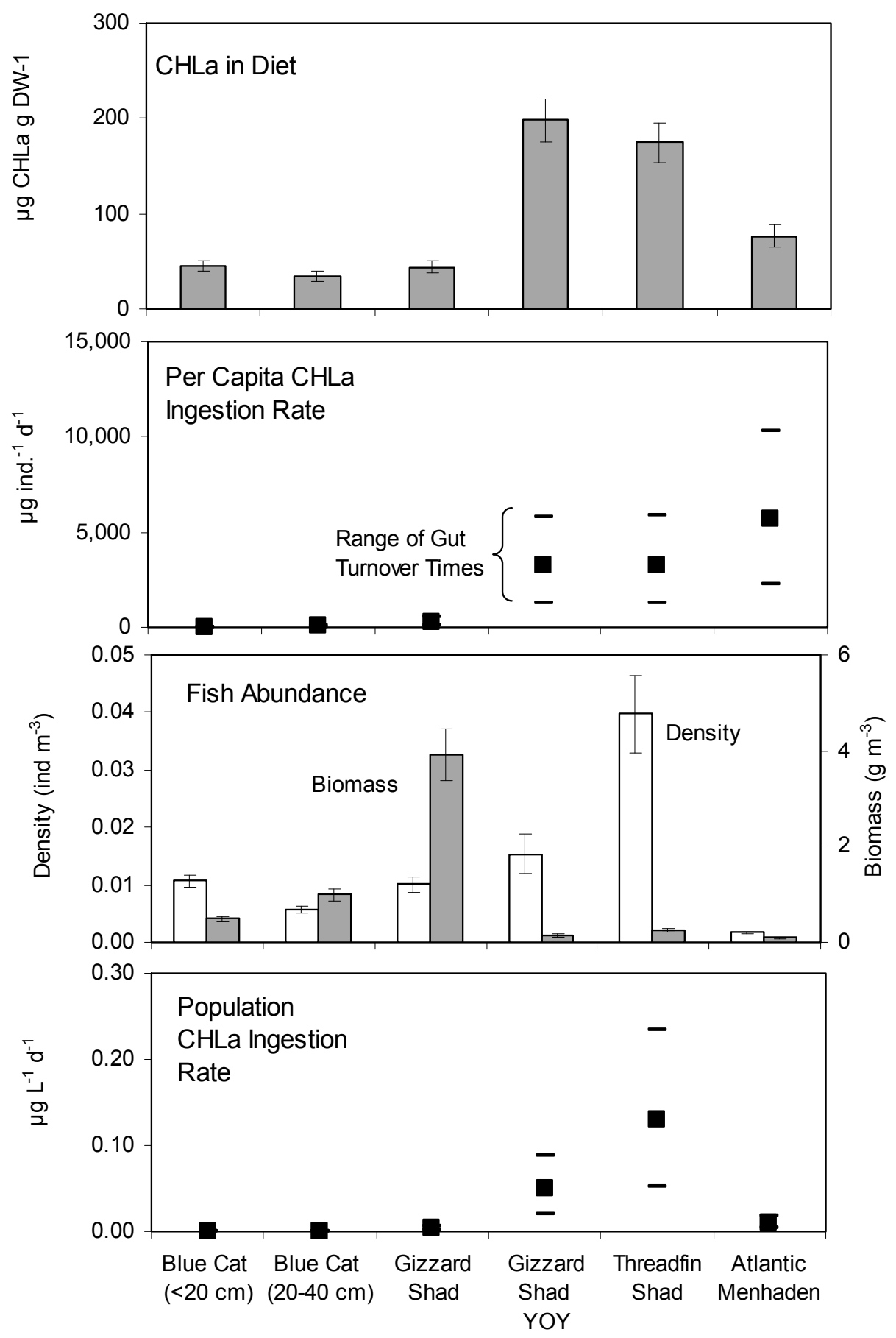

Figure 2. Fish as consumers of CHLa in the tidal freshwater James River (VA, USA). Data shown are (top) CHLa in fish gut contents (with standard error), $\left(2^{\text {nd }}\right)$ per capita CHLa ingestion for a range of gut turnover rates, $\left(3^{\text {rd }}\right)$ fish biomass and density (with standard error) and (bottom) population-scale estimates of CHLa ingestion for a range of gut turnover times (YOY = young of the year). 

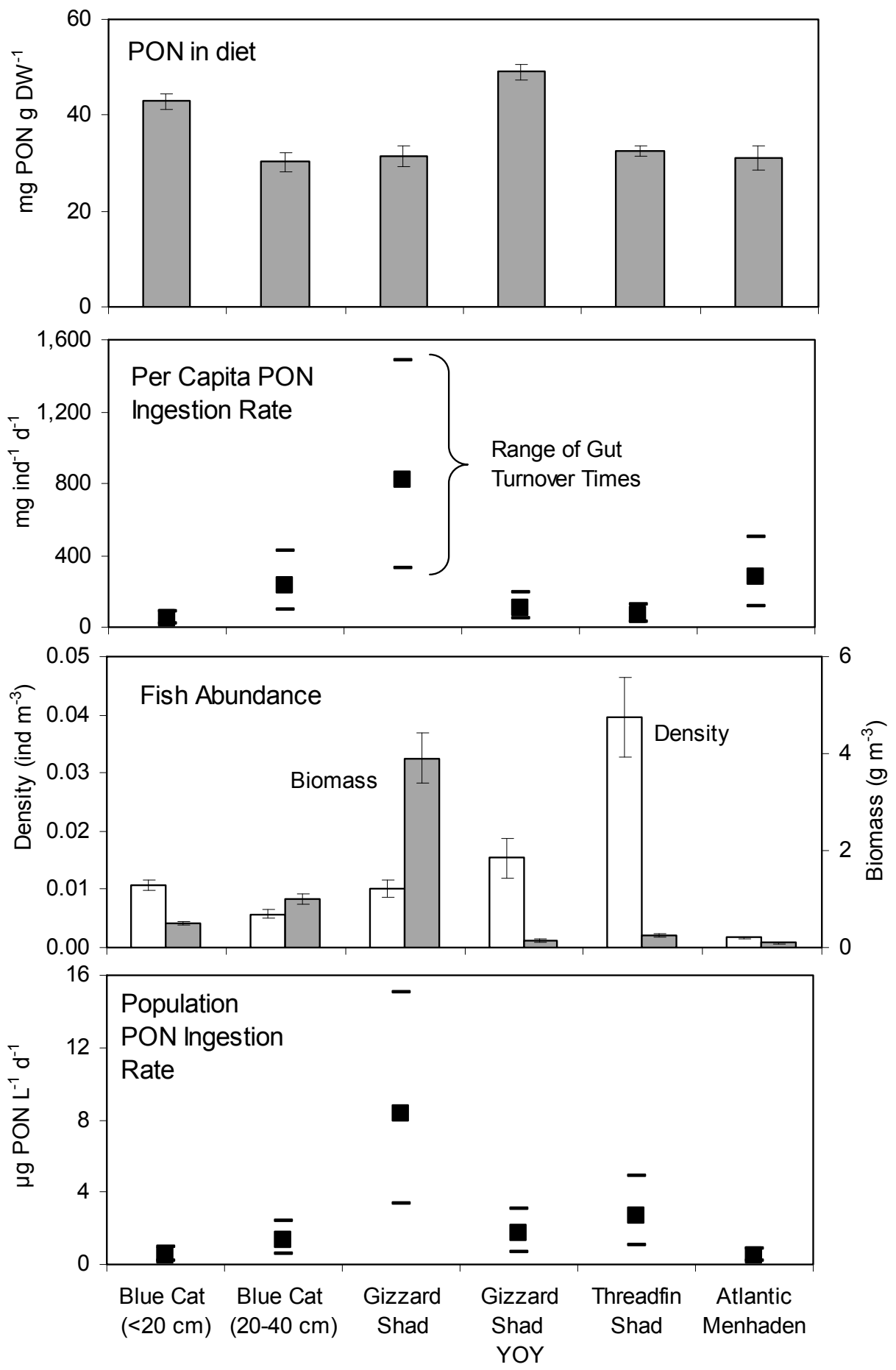

Figure 3. Fish as recyclers of $\mathrm{N}$ in the tidal freshwater James River (VA, USA). Data shown are (top) PON in fish gut contents (with standard error), $\left(2^{\text {nd }}\right)$ per capita PON ingestion for a range of potential gut turnover rates, $\left(3^{\text {rd }}\right)$ fish abundance (as shown in Fig. 1) and (bottom) populationscale estimates of PON ingestion (for range of gut turnover times). 

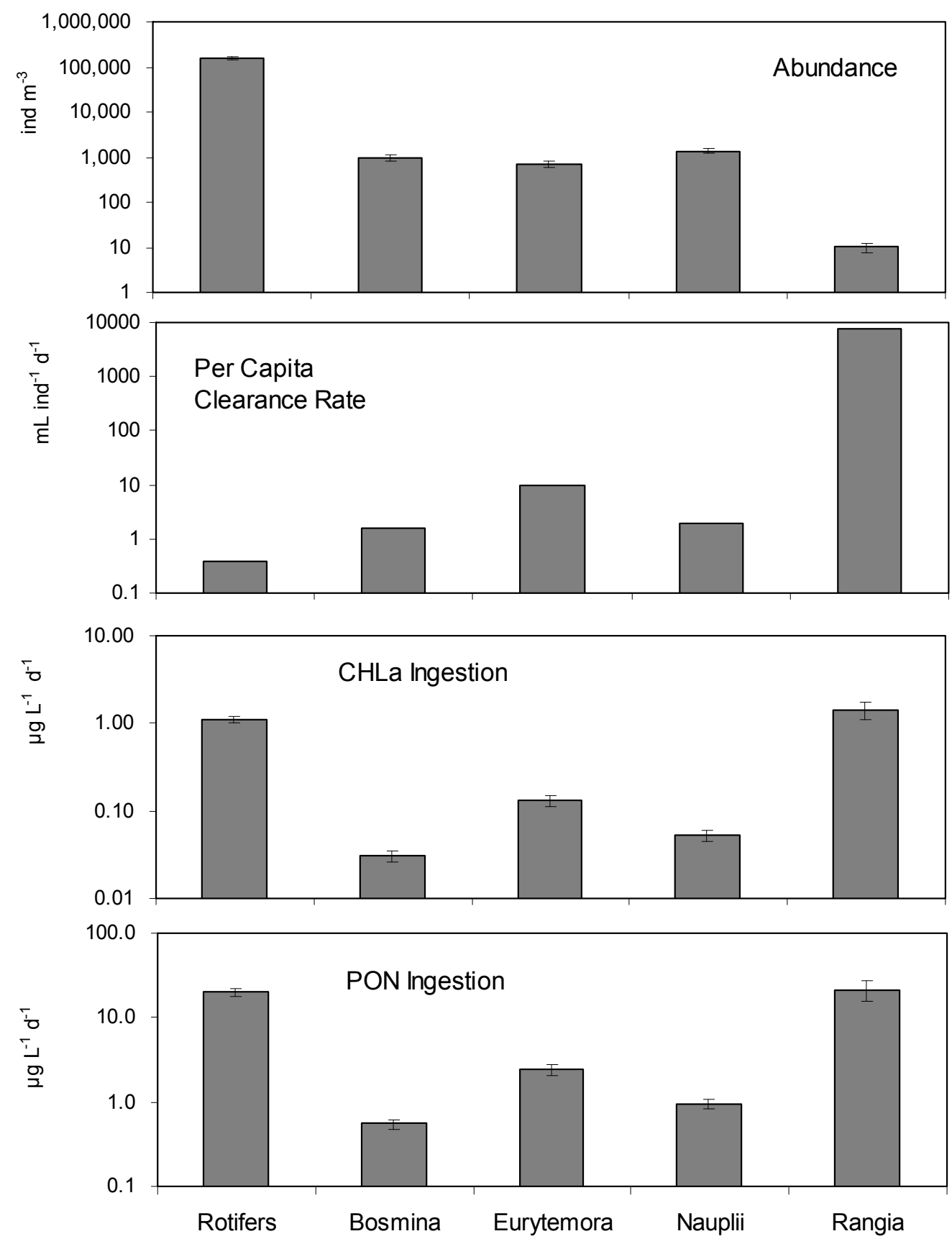

Figure 4. Abundance, per capita clearance rates and CHLa and PON ingestion by dominant zooplankton and benthic filter-feeders (Rangia) of the tidal freshwater James River (VA, USA). Zooplankton abundances are based on bi-monthly collections during March-September 2013. Rangia abundance is the average for 2001-2010 based on annual surveys by CBP. Error Bars denote \pm SE. 


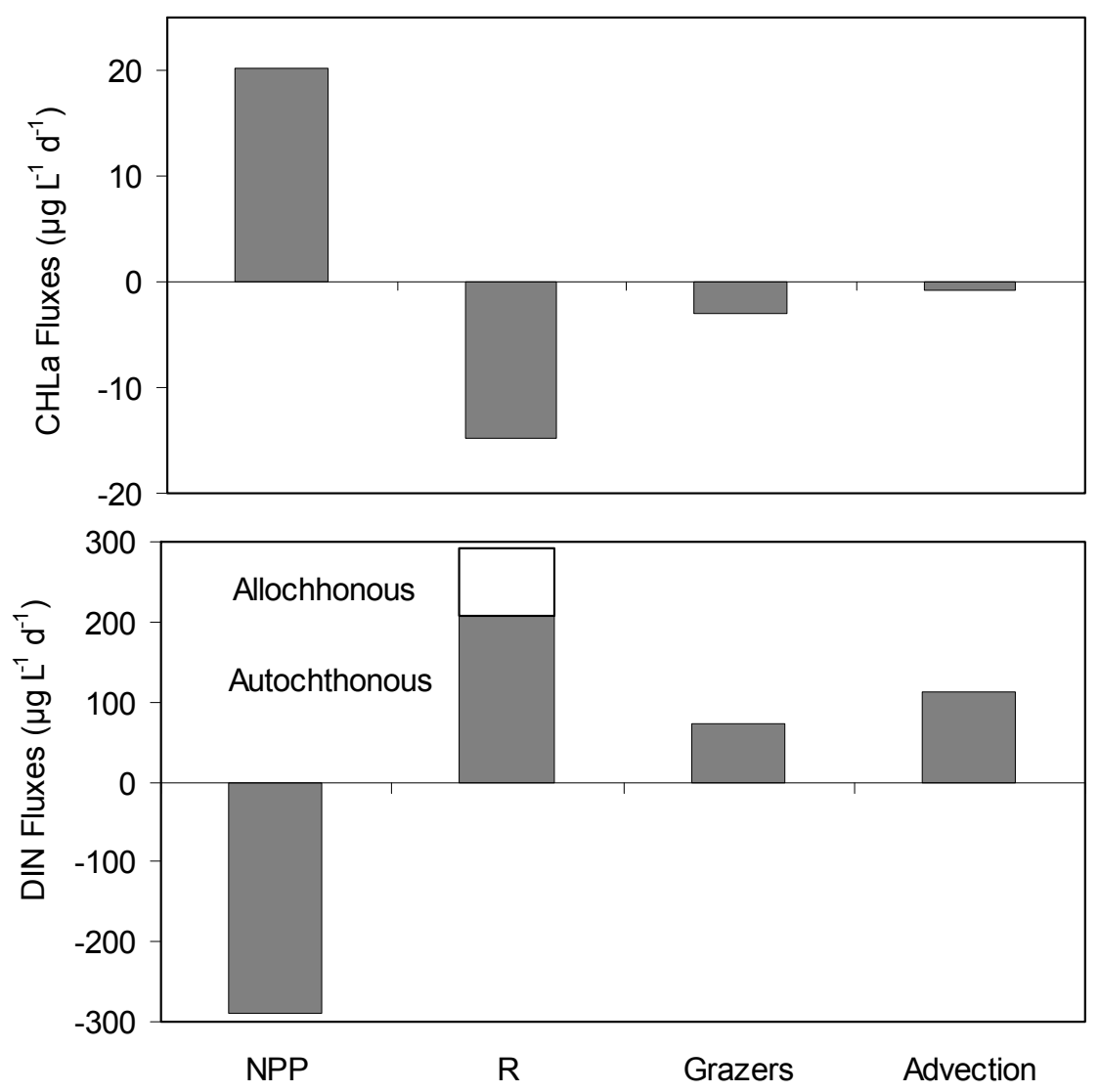

Figure 5. (Top) CHLa production by phytoplankton (NPP) compared to losses via respiration (R), grazing and advection (export). (Bottom) Phytoplankton demand for DIN compared to inputs via respiration (re-mineralization), consumer-mediated $\mathrm{N}$ cycling (grazing), and advection (external inputs). Data shown are average daily values for March-November of 2012 and 2013. Grazing losses include contributions by zooplankton, benthic filter-feeders and fish. 


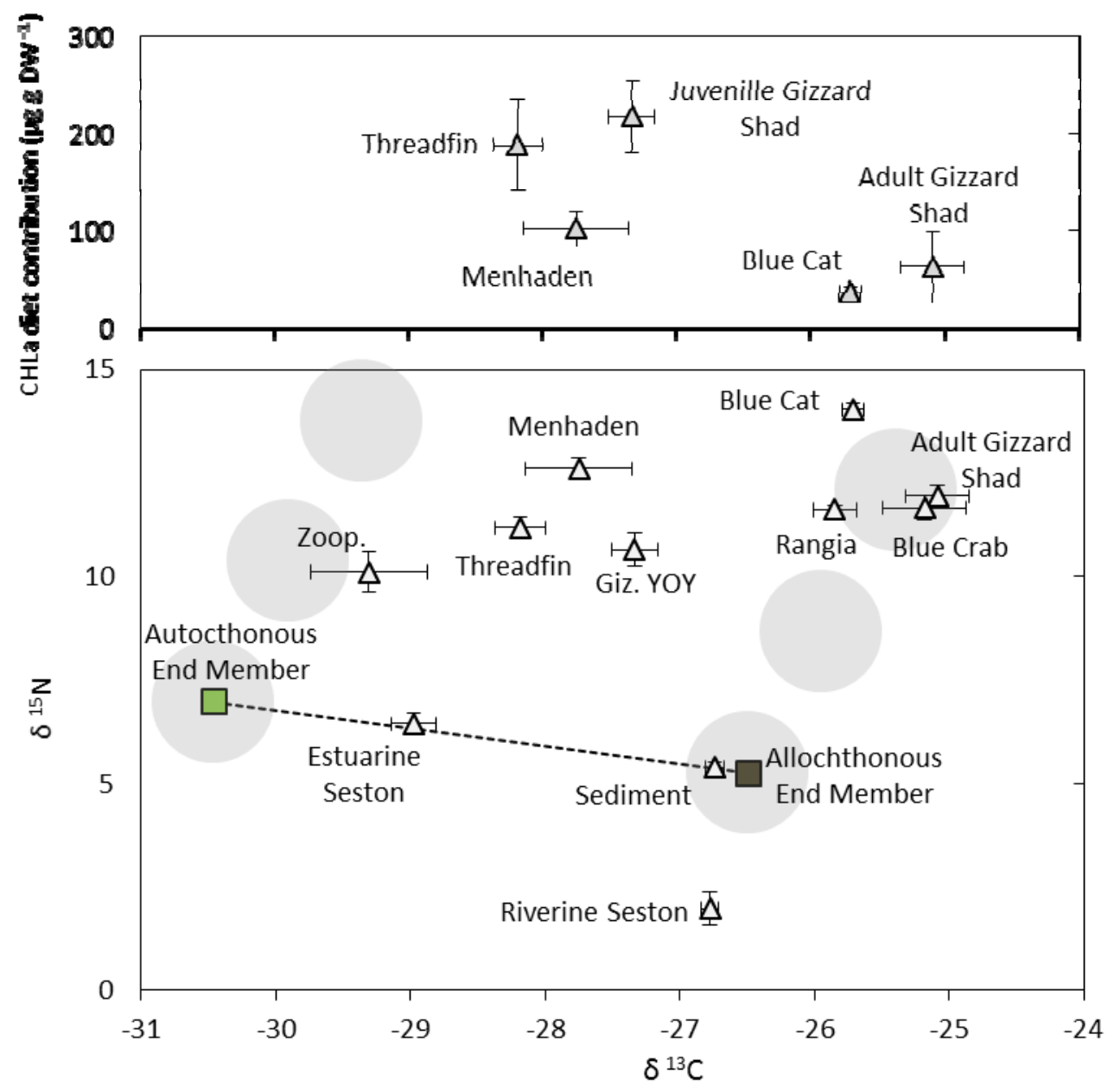

Figure 6. (Top) $\mathrm{CHLa}$ of gut contents and $\delta^{13} \mathrm{C}$ of dominant fish species from the tidal fresh James River (VA, USA). (Bottom) $\delta{ }^{13} \mathrm{C}$ and ${ }^{15} \mathrm{~N}$ in seston, sediment and consumers from the James. Large grey circles represent estimated trophic level enrichments; squares are derived autochthonous and allochthonous end members (error bars denote SE). 

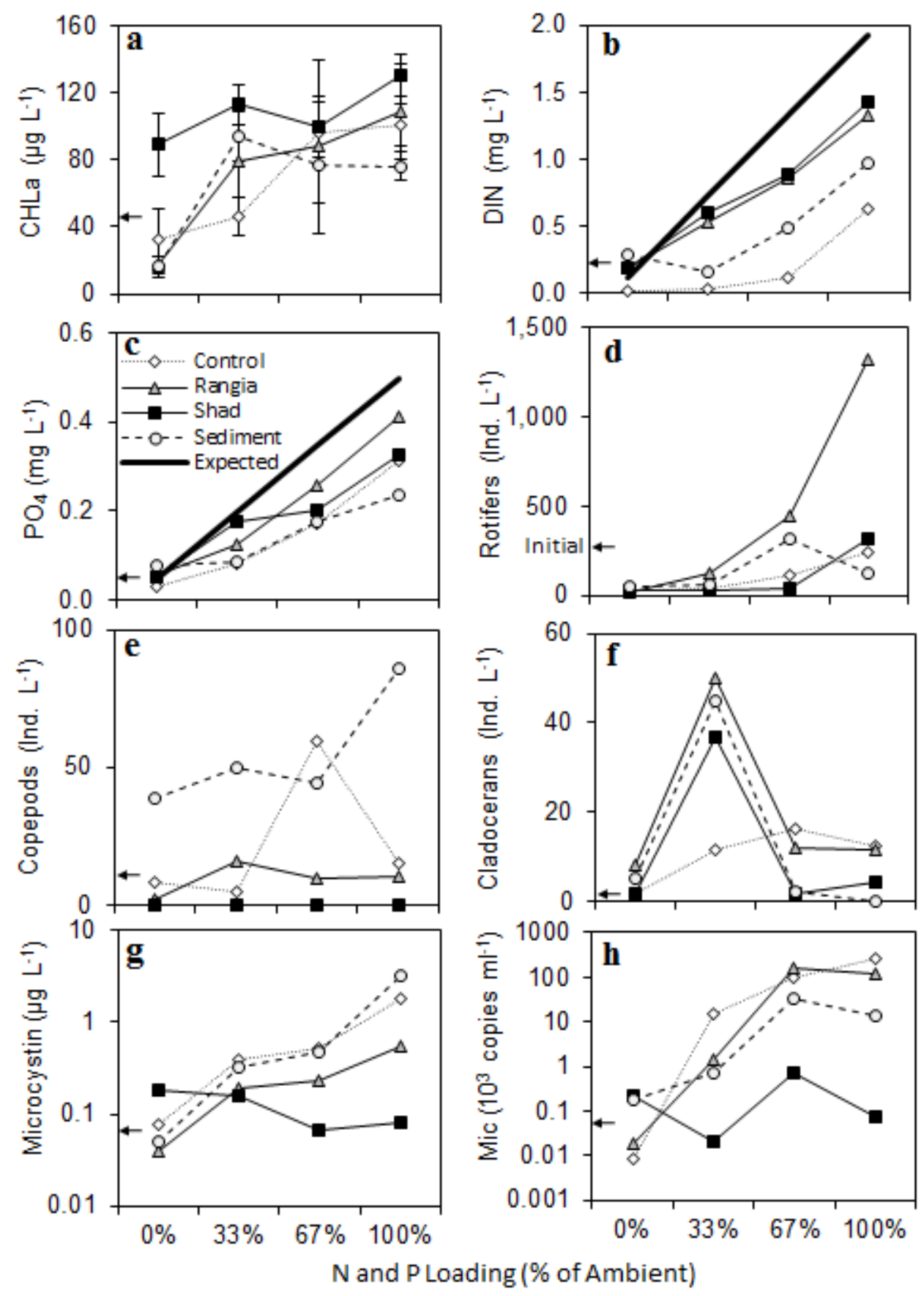

Figure 7. Effects of nutrient enrichment and the presence of consumers on CHLa, dissolved inorganic nutrients, zooplankton, Microcystin and Microcystis gene copies (Mic). Data represent averages $\pm \mathrm{SE}(\mathrm{CHLa})$ or final values (nutrients, zooplankton Microcystin, Mic) for the 15-day mesocosm experiment. Arrows denote initial (Day 0) values; solid lines are expected concentrations of DIN and $\mathrm{PO}_{4}$ based on rates of addition. 